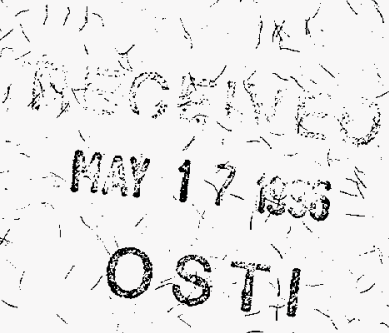

\title{
Scoping Measurements of Radionuclides in LLake with an Underwater HPGe Detector $(\mathrm{U})$
}

Westinghouse Savannah River Company Savannah River Site Aiken, SC 29808

Prepared for the U.S. Department of Energy under contract no. DE-AC09-89SRI8035 


\section{DISCLAIMER}

This report was prepared as an account of work sponsored by an agency of the United States Government. Neither the United States Government nor any agency thereof, nor any of their employees, makes any warranty, express or implied, or assumes any legal liability or responsibility for the accuracy, completeness, or usefulness of any information, apparatus, product, or process disclosed, or represents that its use would not infringe privately owned rights. Reference herein to any specific commercial product, process, or service by trade name, trademark, manufacturer, or otherwise does not necessarily constitute or imply its endorsement, recommendation, or favoring by the United States Government ar any agency thereof. The views and opinions of authors expressed herein do not necessarily state or reflect those of the United States Government or any agency thereof.

This report has been reproduced directly from the best available copy.

Available to DOE and DOE contractors from the Office of Scientific and Technical Information, P.O. Box 62, Oak Ridge, TN 37831; prices available from (615) 576-8401.

Available to the public from the National Technical Information Service, U.S. Department of Commerce, 5285 Port Royal Road, Springfield, VA 22161. 
Scoping Measurements of Radionuclides in L Lake with an Underwater HPGe Detector(U)

D. L. Dunn

W. G. Winn

Environmental Technology Section

Savannah River Technology Center

P. J. Bresnahan

Department of Geography

University of South Carolina

Prepared for the U.S. Department of Energy under contract no. DE-AC09-89SR 18035 



\section{Contents}

Executive Summary

Introduction

Methods

Measurements and Analysis

Radiation Levels of ${ }^{137} \mathrm{Cs}$ in L Lake

Radiation Levels of ${ }^{60} \mathrm{Co}$ in L Lake

Contouring

8

8

Discussion of Results

Acknowledgments

8

References

Appendix A. Data - Underwater HPGe Measurements

Appendix B. Data - Analysis of Sediments

Appendix C. Dose Conversions

Dose Conversions for ${ }^{137} \mathrm{Cs}$

Dose Conversions for ${ }^{60} \mathrm{Co}$

Bulk DR of L Lake per EG\&G Data

Maximum DR of $L$ Lake per EG\&G Data

Appendix C References 


\section{List of Figures}

Figure 1. August 1985 Aerial View of Steel Creek and the L Lake Project

Figure 2. Pontoon Boat equipped with HPGe Detector, Associated Electronics, and a Hoist for Lowering the Detector into Sampling Position

Figure 3. Detector Assembly Unit with HPGe Detector Probe and Liquid Nitrogen Dewar

Figure 4. 1995 Underwater Detector ${ }^{137} \mathrm{Cs}$ Count Rate point data relative to 1985 EG\&G Overflight Dose

Figure 5. ${ }^{137} \mathrm{Cs}$ Count Rate Contours With Underwater HPGe

Figure 6. ${ }^{137} \mathrm{Cs}$ Isodose Contours from 1985 EG\&G Overflight NaI Mappings

Figure 7. Map of Sediment Radionuclide Concentrations

Figure 8. ${ }^{60} \mathrm{Co}$ Isodose Contours from 1985 EG\&G Overflight NaI Mapping

Figure 9. Triangulated Irregular Network Model Projection of $1995{ }^{137} \mathrm{Cs}$ Distribution

Figure 10. Borrow Pit Examination

Figure 11. ${ }^{137} \mathrm{Cs}$ Conservative 1995 Isodose Contours 


\section{Executive Summary}

This study of L Lake was conducted to determine whether the distribution of man-made radiation levels had changed from the time preceding the filling of the newly created lake in 1985 . Overflight gamma measurements by $E G \& G$ in 1985 mapped the man-made radiation levels, indicating that significant levels were only detected from former stream beds that were to be covered by the lake. the present scoping gamma measurements were consistent with these earlier findings, indicating no major evidence of movement of the radioactivity. These results will be available to guide decisions concerning future plans for the lake. ${ }^{1}$
Gamma-emitting radionuclides of $\mathrm{L}$ Lake were examined in situ with an underwater HPGe detector and further studied by retrieving various sediment samples for analysis by HPGe gamma spectrometry in the Underground Counting Facility. The predominant man-made radionuclide detected was ${ }^{137} \mathrm{Cs}$; it had about 100 times greater activity than ${ }^{60} \mathrm{Co}$, which was the only other man-made radionuclide that was detected above trace levels. 


\section{Introduction}

A radiological distribution survey at the $L$ Lake on the Savannah River Site (SRS) was conducted from August 1, 1995 to August, 15 1995, by the Savannah River Technology Center (SRTC), Environmental Technology Section (ETS). The work was requested by the SRTC Environmental Sciences Section (ESS) as part of a larger project to examine future alternatives for L Lake and other SRS water bodies. ${ }^{1}$

The primary purpose of the present survey was to confirm previous radionuclide surveys of cesium-137 $\left({ }^{137} \mathrm{Cs}\right)$ in the $L$ Lake area. EG\&G Energy Measurements, Inc. (EG\&G/EM) conducted an aerial baseline radiological survey of the L Lake area and the Steel Creek drainage basin in 1985. Overflight gamma mappings of the area by EG\&G indicated that the only significant man-made radionuclides were located in the stream beds, ${ }^{2}$ which were subsequently covered by the reservoir. Recent underwater HPGe detector studies of Par Pond ${ }^{3-5}$ and Pond $C^{5-6}$ indicate that similar studies on $L$ Lake could appraise whether the 1985 radiation distributions of $L$ Lake are still valid. The major concern is to see whether any of the man-made radiation has migrated away from the stream beds.
An underwater HPGe detector was used to scope the possibility of sediment redistribution from the stream beds beneath $L$ Lake. Unlike earlier studies ${ }^{3-7}$, only the radiation levels were sought as opposed to the radionuclide inventory of the lake sediment. The underwater HPGe detector was positioned to view the bottom sediment. The count rate is proportional to the radiation level that would be observed if the lake water were absent, as in the 1985 overflight measurements. ${ }^{2}$ Thus, the present study yields count rate profiles that are appropriate for comparison with the gamma mappings of 1985 . By contrast, to appraise the radioactive inventory of $L$ Lake, the depth distribution of the activity within the sediment would need to be determined from segmented sediment cores. Although ETS did not collect such segmented core samples, grab samples of the bottom sediment were collected. The grab samples were analyzed by low-level HPGe gamma spectrometry in the Underground Counting Facility to determine man-made radionuclides below the detection limit of the underwater HPGe detector. 


\section{Methods}

Step sampling is most useful for characterizing the edge of an area of contamination. The project's goals require that the edge of any ${ }^{137} \mathrm{Cs}$ migration from the original Steel Creek bed be identified. (An aerial view of the Steel Creek and the L Lake dam obtained during the August 1985 EG\&G/EM survey is shown in Figure 1. At the time of the photo, most of the excavation work for the lake had been completed.) The real-time data obtained from the underwater HPGe detector was used to refine the sampling plan while in the field. The key to step sampling is to ensure that the first samples are collected far enough away from the source to be considered natural background samples. Real-time measurements from an underwater HPGe detector were used to map the sediment ${ }^{137} \mathrm{Cs}$ on the lake bottom, using the step sampling approach. Progressive steps were taken along the same transect line between the first point and the known source using water depth increments (typically 4 feet) to define the steps. Steps based on depth increments help establish the distribution of contamination. Previous studies have shown that contamination will typically be found at the deeper depths. ${ }^{3-6}$ If the sampling point was a "hit" for ${ }^{137} \mathrm{Cs}$ contamination, the next step was taken away from the known source. Alternately, if the sample was a "miss", a progressive step was taken toward the known source. The edge of the ${ }^{137} \mathrm{Cs}$ contamination was resolved in five or six steps.

The step method does not characterize contamination in the entire lake as well as grid sampling methods; however it is much more cost effective. If the scope of this project is expanded, grid sampling techniques within the conservatively estimated contamination zone would be an appropriate sampling plan.

The overall equipment has been described in detail in the reports on the Par Pond ${ }^{3-5}$ and Pond $C^{5-6}$ The underwater
HPGe detector was operated from a pontoon boat, as shown in Figure 2. The detector has about $30 \%$ efficiency, relative to a standard comparison with a 3 -inch by 3 -inch $\mathrm{NaI}$ detector. Figure 3 is a photograph of the detector and its liquid nitrogen dewar, both of which are contained within a screen housing. The housing serves to protect the detector from impact damage and also defines the sediment counting geometry. The detector was lowered by a winch through a trap door of the boat deck.

A $5 \mathrm{kVA}$ gasoline generator was used to energize an uninterruptable power supply (UPS), which in turn provided reliable clean power for the electronics. A compact EG\&G NOMAD ${ }^{\mathrm{TM}}$ unit provided the detector electronics and multichannel analyzer (MCA), which were controlled by a Lite/253 (COMPAQ) notebook computer. All these units fit into the NOMAD case, resulting in a "briefcase" system for the computer and electronics. With the detector lowered to the bottom sediment, one-minute HPGe spectra were collected, yielding the count rate of the $662 \mathrm{keV}$ gamma of ${ }^{137} \mathrm{Cs}$. Geographic position measurements were made using a Motorola TRACKER ${ }^{\circledR}$ portable geographic positioning system (GPS) unit. The lake depth was determined with a Lowrance ${ }^{\circledast}$ depth finder. Geographic position and depth were used in developing the contour plots generated in this study.

Grab samples of sediment were collected using a clam shell style, sediment sampler. The sediment sampler was lowered from the pontoon boat to rest on the sediment surface. A messenger weight was released along the cable to trigger the collection. Geographic position and depth were recorded as described above. Sediment samples of about 150 grams were placed in standard 64-mm diameter counting vials and counted overnight or longer in the Underground Counting Facility. ${ }^{8}$ 


\section{Measurements and Analysis}

Underwater HPGe detector measurements of the lake-bottom radioactivity were conducted at locations given in Figure 4, along transects identified in Figure 5. Transects 1-7 were performed to survey the general distribution of manmade radionuclides in L Lake while transects 8-12 examined specific locations designated by ESS, where excavation work could have potentially redistributed these activities. The raw data from these measurements are recorded in Appendix A where each measurement is characterized by its location coordinates, pond depth, and ${ }^{137} \mathrm{Cs}$ count rate. These data were used in developing the ${ }^{137} \mathrm{Cs}$ count-rate contours of Figure 5, which are distributed similarly to the earlier EG\&G overfight isodose contours $^{2}$ shown in Figure 6.

All underwater HPGe spectra of the lake bottom surface were counted for one minute and saved on disk. At each location, the detector was lowered to rest on the lake bottom, so that the protective screen mesh about the detector defined the same counting geometry for each measurement of bottom surface radiation. Measurements at 96 locations were made. The count rates of the $662 \mathrm{keV}$ gamma of ${ }^{137} \mathrm{Cs}$ were determined and recorded in the field by utilizing the MAESTRO ${ }^{\mathrm{TM}}$ peak-fitting capability of the MCA software. The depth and position were read and recorded along with each spectral count. Various quality checks were applied to appraise the measurements. Suspiciously low count rates were remeasured after slight repositioning of the detector on the bottom to ensure that obstructions such as stumps did not displace the detector from the bottom sediment. After each measurement, any muddy sediment sticking to the bottom screen was removed to prevent cross contaminating measurements from one site to another. Before, during, and after each series of measurements, a ${ }^{60} \mathrm{Co} /{ }^{137} \mathrm{Cs}$ calibration source was used to assure proper detector operation; a total of 19 calibration checks were made during the measurements. All field results were reviewed and refined as appropriate at the laboratory.

At 20 locations shown in Figure 7, sediment samples were retrieved from the lake bottom. These samples were dried and counted overnight or longer on either the $90 \%$ - or $166 \%$-efficient HPGe detectors of the Underground Counting Facility. ${ }^{8}$ These samples had ${ }^{137} \mathrm{Cs}$ concentrations ranging from 200 to $34,000 \mathrm{pCi} / \mathrm{kg}$. Other than ${ }^{137} \mathrm{C}$, the only man-made isotope observed was ${ }^{60} \mathrm{Co}$, which was present at levels two orders of magnitude lower than those for ${ }^{137} \mathrm{Cs}$; the ${ }^{60} \mathrm{Co}$ concentrations ranged from 0 to $600 \mathrm{pCi} / \mathrm{kg}$. One of the samples indicated some evi- dence of trace levels of ${ }^{154} \mathrm{Eu}$ at $-20 \mathrm{pCi} / \mathrm{kg}$. Appendix B details these sample results, which are representative of the top few centimeters of sediment.

The underwater HPGe detector did not count long enough to detect these lower ${ }^{60} \mathrm{Co}$ activities sufficiently to produce a count-rate contour map; however, a map of ${ }^{60} \mathrm{Co}$ dose levels was produced by the $\mathrm{NaI}$ overflight measurements, ${ }^{2}$ and this is given in Figure 8. Overall, the ${ }^{60} \mathrm{Co}$ and ${ }^{137} \mathrm{Cs}$ contour maps are similarly distributed. This is consistent with the relative uniformity for the majority of ${ }^{60} \mathrm{Co} /{ }^{137} \mathrm{Cs}$ ratios of 1-2\% shown in Figure 7. However, an exception to this is noted in the vicinity of the L Reactor discharge channel where the observed ${ }^{60} \mathrm{Co} /{ }^{137} \mathrm{Cs}$ range up to $6 \%$.

\section{Radiation Levels of ${ }^{137} \mathrm{Cs}$ in L Lake}

The ${ }^{137} \mathrm{Cs}$ radiation levels in $\mathrm{L}$ Lake are of primary concern since ${ }^{137} \mathrm{Cs}$ is the predominant man-made gammaemitting radionuclide present. For annual dose estimates near the surface, it was deduced that a conversion factor of $0.5 \mathrm{mrem} / \mathrm{cpm}$ appears appropriate for conservative estimates, and a factor of $0.3 \mathrm{mrem} / \mathrm{cpm}$ may be used for more realistic estimates. The basis for these conversion factors is outlined as follows.

The annual ${ }^{137} \mathrm{Cs}$ dose levels based on the EG\&G overflights of the empty L Lake in 1985 had contours of annual dose ranging from $(0-4)$ to $(112-240) \mathrm{mrem}$, or $(0-3)$ to (89-191) mrem when decay-corrected to 1995 levels. It is fortuitous but useful in comparison that the ${ }^{137} \mathrm{Cs}$ count rates measured with the underwater HPGe detector have a comparable numerical range of $0-381 \mathrm{cpm}$, suggesting that a useful conversion would be in the range of $0.23-0.50$ $\mathrm{mrem} / \mathrm{cpm}$. To test this supposition, the earlier point source calibration information ${ }^{4}$ was back-calculated to predict a dose conversion factor of $0.0304<\mathrm{e}^{\mu \mathrm{t}}>\mathrm{mrem} / \mathrm{cpm}$. The factor $\left\langle\mathrm{e}^{\mu t}\right\rangle$ is the average air-to-water attenuation correction that addresses the lower count rate observed due to the water media. The calculations are described in Appendix $\mathrm{C}$, but have model-dependent limitations. Nevertheless, $\mathrm{a}\left\langle\mathrm{e}^{\mu \mathrm{t}}\right\rangle$ of $\sim 10$, which corresponds to an effective water thickness $t$ of $\sim 10$ inch, appears reasonable and yields $\sim 0.3 \mathrm{mrem} / \mathrm{cpm}$, which lies within the range suggested by the overfight data. Accordingly, respective factors of $0.3 \mathrm{mrem} / \mathrm{cpm}$ and $0.5 \mathrm{mrem} / \mathrm{cpm}$ are selected for best and conservative estimates of annual dose for any areas exposed via lake drainage. 
Another factor of interest is the sediment activity/countrate conversion, which when given in units of $\mu \mathrm{Ci} / \mathrm{m}^{2} / \mathrm{cpm}$ permits calculation of the $\mathrm{Ci}$ inventory for areas of the lake bottom. The goals of the present study did not include $\mathrm{Ci}$ inventories, and no direct effort was expended to produce a conversion factor for this. On the other hand, a factor of $0.0171 \mu \mathrm{Ci} / \mathrm{m}^{2} / \mathrm{cpm}$ had been deduced earlier for Par Pond sediments ${ }^{4}$ using segmented core data provided by SREL. ${ }^{9}$ Although this conversion factor is not directly applicable to L Lake, particularly in the stream bed where the bulk of the activity was observed, it should provide $\mathrm{L}$ Lake estimates within an order of magnitude. Indeed, model calculations ${ }^{4}$ of uniformly distributed ${ }^{137} \mathrm{Cs}$ activities located within sediment to depths of $1-30 \mathrm{~cm}$ yielded corresponding conversions of $0.008-0.029 \mu \mathrm{Ci} / \mathrm{m}^{2} / \mathrm{cpm}$, which are within a factor of -2 of the Par Pond conversion factor.

\section{Radiation Levels of ${ }^{60} \mathrm{Co}$ in L Lake}

The present measurements of the ${ }^{60} \mathrm{Co}$ radiation levels also appear consistent with the earlier EG\&G overflight results, as based on detailed analyses given in Appendix $C$. These analyses indicate that the EG\&G doses in the Steel Creek stream bed project a ${ }^{60} \mathrm{Co} /{ }^{137} \mathrm{Cs}$ dose ratio of $0.053 \pm 0.006$ for 1995. Appendix B indicates that the bulk of the sediment samples taken in 1995 indicated a ${ }^{60} \mathrm{Co} /{ }^{137} \mathrm{Cs}$ concentration ratio of $1.47 \pm 0.08 \%$, which yields a dose ratio of $0.060 \pm 0.003$, in reasonable agreement with the overflight value. It is interesting that the overfight results show relatively more ${ }^{60} \mathrm{Co}$ in the $\mathrm{L}$ discharge canal than was observed for ${ }^{137} \mathrm{Cs}$, which is consistent with the higher ${ }^{60} \mathrm{Co} /{ }^{137} \mathrm{Cs}$ concentration ratio observed in the 1995 sediments in this vicinity. The largest $1995{ }^{60} \mathrm{Co} /{ }^{137} \mathrm{Cs}$ concentration ratio of $5.98 \pm 0.19 \%$ corresponds to a dose ratio of $0.24 \pm 0.01$, which is consistent with a crude 1995 estimate of $0.27 \pm 0.10$ from the overflight contours.

\section{Contouring}

Manual $1995{ }^{137} \mathrm{Cs}$ isodose rate contours are shown in Figure 5. Manual $1985{ }^{137} \mathrm{Cs}$ isodose rate contours are shown in Figure 6. Spatial distributions of ${ }^{137} \mathrm{Cs}$ are shown in both cases as isodose rate contours. The contours are developed by qualified professionals using ${ }^{137} \mathrm{Cs}$ measurements, location coordinates, and spatial orientation. Manual interpolation may be used to smooth out known features and unknown anomalies in the isodose rate contours.

Some effort was made in the current study to generate the ${ }^{137} \mathrm{Cs}$ isodose rate contours using computer methods. Measurements of $1995 \mathrm{HPGe}{ }^{137} \mathrm{Cs}$ sample count rates were georegistered as point coverage in an $\mathrm{ARC}_{\mathrm{NNFO}}{ }^{\circledR}$ format. ARC/INFO ${ }^{\circledR}$ is a geographic information system database developed and marketed by the Environmental Systems Research Institute (ESRI). The data were converted to dose by applying the conservative conversion as described above in Radiation Levels of ${ }^{137} \mathrm{Cs}$ in L Lake. For the ${ }^{137} \mathrm{Cs}$ coverage, the sample points were used to create a statistical surface from which contours could be derived. To create such a surface, the dose values were used as the $Z$ dimension in a spatial data model. The model chosen for this project was a triangulated irregular network (TNN). A TWN was used for its capacity to adjust to heterogeneous distributions of data. Once the TIN was created, contours were generated from the surface. Unfortunately, the resulting contours were inconclusive in that they did not fittingly represent the known distribution of ${ }^{137} \mathrm{Cs}$ activity along the old Steel Creek channel. This result was directly related to the relatively small number of underwater HPGe sample points within L Lake. With any spatial data model, an increase in sample points results in a better depiction of the true spatial distribution.

An attempt to improve the continuity of the generated contours was made by applying information concerning the known distribution of ${ }^{137} \mathrm{Cs}$ activity along the old Steel Creek channel. The Steel Creek channel was digitized from a 1985 aerial photograph and was saved within the model as an ARCMNFO line coverage. This coverage was included in the TIN building method to provide a soft breakline that was to force contouring onto opposite sides of the channel. Again, the relatively small number of samples limited the effectiveness of this approach.

Additional grid sampling within the old floodplain of the Steel Creek channel is required to obtain the necessary data and spatial coverage for continuous computer generated isodose contours. If the 1985 EG\&G raw data were available, simple regression analysis and spatial autocorrelation could be applied to compare 1985 and 1995 distribution of ${ }^{137} \mathrm{Cs}$ activity.

Manually interpolated $1995{ }^{137} \mathrm{Cs}$ isodose rate contours are shown in Figure 5 based on high spatial resolution point data from the underwater HPGe measurements. The contours shown are narrow, essentially restricting the ${ }^{137} \mathrm{Cs}$ activity distribution to the creek channel. The computer-generated case for this $1995{ }^{137} \mathrm{Cs}$ activity distribution is shown in Figure 9. A mesh was draped over the TIN so that dose values in the $\mathrm{Z}$ dimension are visible; however, the paucity of measurements prevents construction of a continuous isometric plot. The line coverage of the 1985 Steel Creek channel and the 1985 EG\&G isodose rate contours are also shown, illustrating clearly that the stream passes directly through the maxima of the contour. 


\section{Discussion of Results}

The present study of L Lake with the underwater HPGe detector indicates no major change in the man-made radionuclide distributions since the lake basin was radiologically mapped by EG\&G in 1985. However, some minor differences were noted. Overall, the contours along the stream bed appear more narrow in 1995. Careful examination of Figures 5 and 6 shows that the ${ }^{137} \mathrm{Cs}$ in the south end of the stream bed was detected somewhat closer to the dam in 1995. Likewise, evidence suggests that the ${ }^{137} \mathrm{Cs}$ associated with the $L$ Reactor discharge canal has moved somewhat southward. Minor discrepancies such as those . mentioned above can be explained by a number of factors discussed as follows.

The spatial resolution afforded by the overflight Nal measurements was less precise than that of direct measurements by the HPGe detector. The 1985 aerial survey of the Steel Creek Corridor was conducted at an altitude of 46 meters (150 feet) with fight line spacings of 76 meters (250 feet). ${ }^{2}$ The count rate accumulated over the 250 foot flight line was plotted as a function of position to provide an isoradiation contour map of the area of interest. Generally, a conversion factor was applied to specific radionuclide count rate to generate estimates of quantities such as dose. The broad contours for ${ }^{137} \mathrm{Cs}$ and ${ }^{60} \mathrm{Co}$ distributions, Figures 6 and 8 respectively, are a direct consequence of statistically weighting counts across the broad counting geometry inherent in the 250-foot flight path above the creek bed. By comparison, the underwater $\mathrm{HPGe}$ detector measurements are direct measurements on the sediment surface. Manual contours produced from these point data are much more narrow, essentially restricting the ${ }^{137} \mathrm{Cs}$ distribution to the creek bed.

It could be argued that part of the earlier broader ${ }^{137} \mathrm{Cs}$ distribution could have been narrowed in the intervening 10 years by a general "washing" migration of surface sediment downward toward the center of the stream bed. Another contribution to remobilization of cesium from sediments is known to occur during anoxic hypolimnion from late April through mid November. Lakes and ponds in the southeastern United States experience thermal stratification in the summer with isolation of the warmer, surface waters (epilimnion) from the deeper, cooler waters (hypolimnion). Anoxia in the hypolimnion produces a reducing environment that causes release of $\mathrm{Fe}, \mathrm{Mn}$, and other metals from the sediments to the hypolimnion. These metals in the hypolimnion are redistributed in the fall when thermal stratification breaks down and the surface and deeper waters are mixed. ${ }^{10,11}$

Close examination of the 1985 aerial photo shows standing water in the south end of the stream bed as a result of a cofferdam, Figure 1. The cofferdam was constructed to withhold and redirect the flow of water from Steel Creek during construction of the L Lake dam. The backflooding of water north of the cofferdam attenuated the intensity of ${ }^{137} \mathrm{Cs}$ and ${ }^{60} \mathrm{Co}$ gamma rays and shrouded the contaminated sediment during the 1985 overflight NaI measurements. Current underwater HPGe detection permits direct measurement of the sediment surface. The ability to directly measure gamma activity that was previously obscured by the standing water provides evidence that ${ }^{137} \mathrm{Cs}$ and ${ }^{60} \mathrm{Co}$ are distributed further south than was apparent in the 1985 aerial survey.

The underwater HPGe measurements indicate narrower ${ }^{137} \mathrm{C}$ contours at the Meyer's Mill Road (Road A-14) than were previously recognized in the 1985 study. These underwater measurements imply that the Meyer's Mill roadbed was somewhat elevated relative to the Steel Creek bed and thus did not become contaminated like the creek bed during the earlier releases. Resolution differences would explain why the apparent narrowing of ${ }^{137} \mathrm{Cs}$ count rate contours was more noticeable for the underwater $\mathrm{HPGe}$ measurements than for the overflight measurements.

Figure 10 is a 1985 aerial photo of the large excavation location or "borrow pit" north of the cofferdam. Per request by the Environmental Sciences Section, the location was examined during Transect 12 . The underwater detector and surface sediment measurements for ${ }^{137} \mathrm{Cs}$ and ${ }^{60} \mathrm{Co}$ were relatively low. In this search area, there was no measurable indication of man-made radiation above normally anticipated background. Segmented sediment cores would be necessary to ascertain the depth distribution of man-made radiation in this and other ESS-selected "pit" locations. Other ESS-selected excavation locations yielded no evidence of "hot" areas by the underwater detector measurements.

The results of this study should be applied in conservative fashion for guiding future decisions regarding $\mathrm{L}$ Lake. Although, the decay-corrected overflight data generally agree with the results obtained in the present study, areas where minor discrepancies exist should use the more con- 
servative higher values. Thus, despite the probable resolution and migration scenarios discussed above, the more broadly distributed overflight radiation levels are recommended as a conservative base distribution for dose. In specific areas where the underwater HPGe yielded a higher dose the radiation level contours should be augmented. In following this scheme, the overflight data, decay-corrected to the 1995 levels, should be used, and the appropriate dose conversion factor (conservative of 0.5 mrem $/ \mathrm{cpm}$ or best estimate of $0.3 \mathrm{mrem} / \mathrm{cpm}$ ) should be used to reshape the count-rate contours of Figure 5.

Figure 11 is a conservative 1995 dose map for ${ }^{137} \mathrm{Cs}$ that was produced using the maximum of the doses for the underwater HPGe results (Figure 5) and the overflight measurements (Figure 6), where the HPGe count rate conversions utilized the conservative $0.5 \mathrm{mrem} / \mathrm{cpm}$. The resulting map implies that the 1995 activity distribution may be down stream and closer to the dam. The 1995 conservative isodose contours appear somewhat elongated in this direction; however, this distention may be an artifice due to the conservative treatment of the HPGe results. In any event, the major activity is still retained in the stream bed. A similar conservative 1995 dose map for ${ }^{60} \mathrm{Co}$ could not be constructed from the available data; however, the dose for ${ }^{60} \mathrm{Co}$ is two orders of magnitude lower than for dominant man-made dose from ${ }^{137} \mathrm{Cs}$. Accordingly, the ${ }^{60}$ Co dose map of Figure 8 should be a sufficient guideline.

\section{Acknowledgments}

The authors thank A. B. Antonicelli, R. R. Penix, and R. J. Roseberry for their in-the-field assistance with the measurements on L Lake. J. B. Gladden, H. E. Mackey, L. Koffman, J. Philpott, and D.W. Hayes are thanked for their technical input concerning this work.

\section{References}

1. DOE (U. S. Department of Energy), "Environmental Assessment For The Natural Fluctuation of Water Level In Par Pond And Reduced Water Flow In Steel Creek Below L Lake At The Savannah River Site", DOE/EA-1070, Savannah River Operations Office, Aiken, SC, (1995).

2. E. L. Feimster, "An Aerial Radiological Survey of L Lake and Steel Creek - Savannah River Site", EG\&G Energy Measurements Report EGG-10617-1146 (November 1992).
3. W. G. Winn, "Evaluation of ${ }^{137} \mathrm{Cs}$ in Pond Sediment with an Underwater HPGe Detector", Trans. Am. Amer. Nuc. Soc., 66, pp 32-34 (1992).

4. W. G. Winn, (1993), Measurements of Radionuclides in Par Pond Sediments with an Underwater HPGe Detector, (WSRC-TR-93-0209), Westinghouse Savannah River Company, Aiken, SC 29801.

5. W. G. Winn, "Environmental Measurements at the Savannah River Site with Underwater Gamma Detectors", Journal of Radioanalytical and Nuclear Chemistry, Vol 194, no. 2, 345-350 (1995).

6. W. G. Winn, Measurements of Radionuclides in Pond $C$ with an Underwater HPGe Detector, WSRC-TR95-0272, Westinghouse Savannah River Company, Aiken, SC 29801 (August 1995).

7. W. H. Carlton, L. R. Bauer, A. G. Evans, L. A. Geary, C. E. Murphy, Jr., J. E. Pinder, and R. N. Strom, Cesium in the Savannah River Site Environment, (WSRC-RP-92-250), Westinghouse Savannah River Company, Aiken, SC 29801 (1992).

8. W. G. Winn, W. W. Bowman, and A. L. Boni, UltraClean Underground Counting Facility for Low-Level Environmental Samples, DP-1747 (September 1987).

9. F.W. Whicker, direct communication on SREL studies of Par Pond.

10. J. J.Alberts, L. J. Tilly, and T. J. Vigerstad, "Seasonal Cycling of Cs-137 in a Reservoir", Science 203:649651 (1979).

11. J. J. Alberts, J. W. Bowling, and K. A. Orlandini, 1987, "The Effect of Seasonal Anoxia on the Distribution of Pu-238, Pu-239, Am-241, Cm-244, and Cs137 in Pond Systems of the Southeastern United States", Pinder, J. E., III, J. J. Alberts, K. W. McLeod, and R. G. Schreckhise (eds.), Environmental Research on Actinide Elements, Office of Scientific and Technical Information, U. S. Department of Energy, Washington, DC, pp. 371-390. 


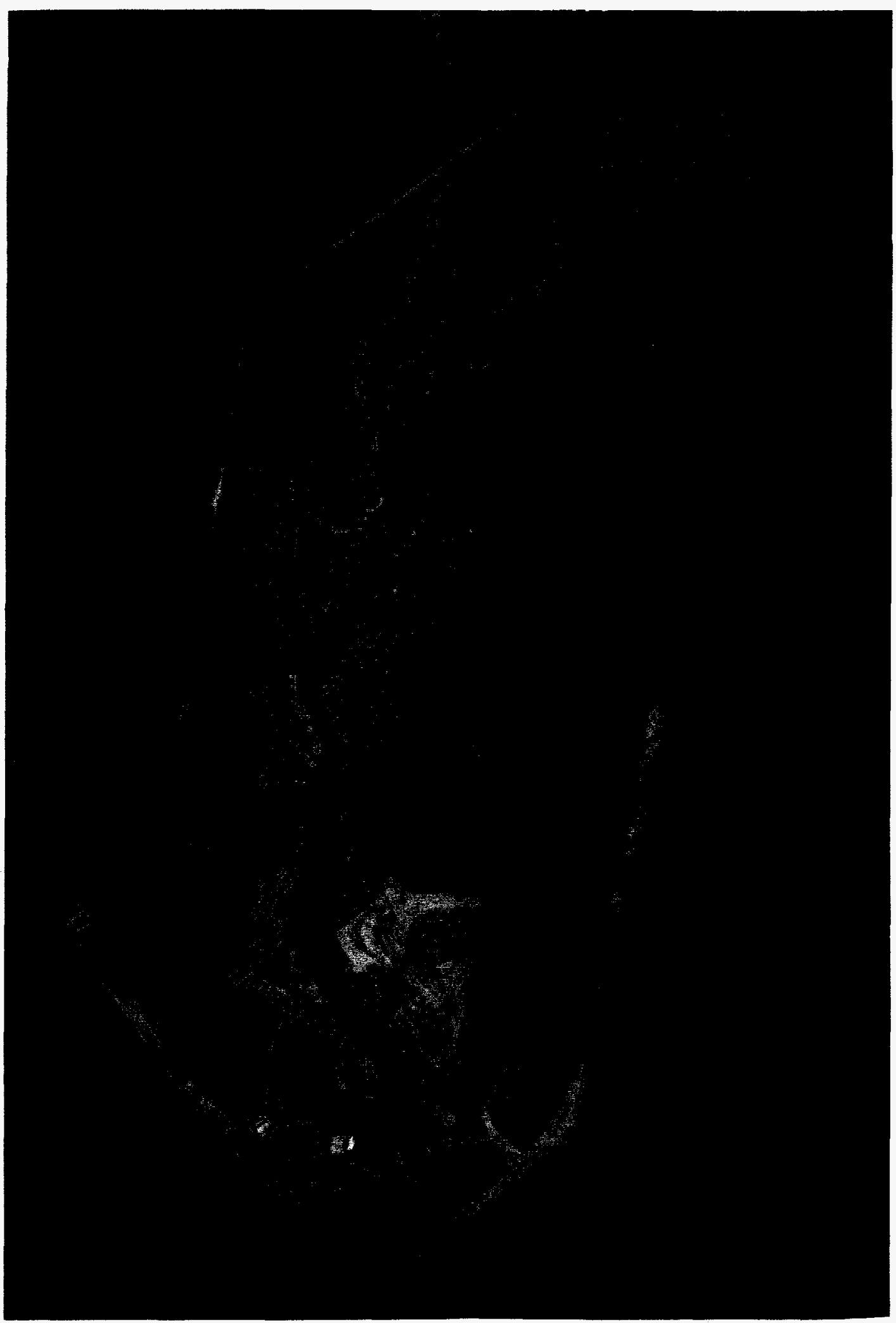

Figure 1. August 1985 Aerial View of Steel Creek and the L Lake Project 


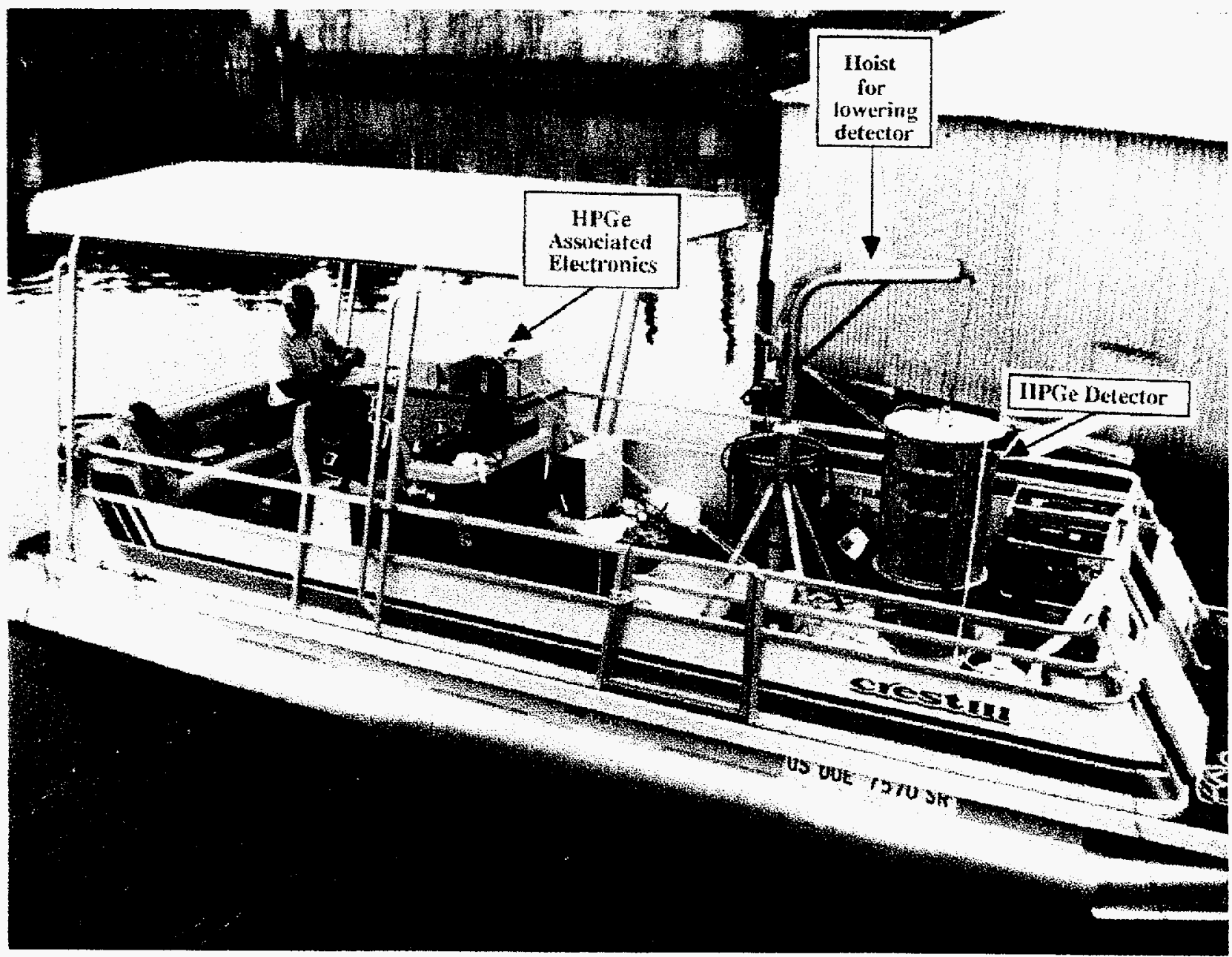

Figure 2. Pontoon Boat Equipped with HPGe Detector, Associated Electronics, and a Hoist for Lowering the Detector into Sampling Position 


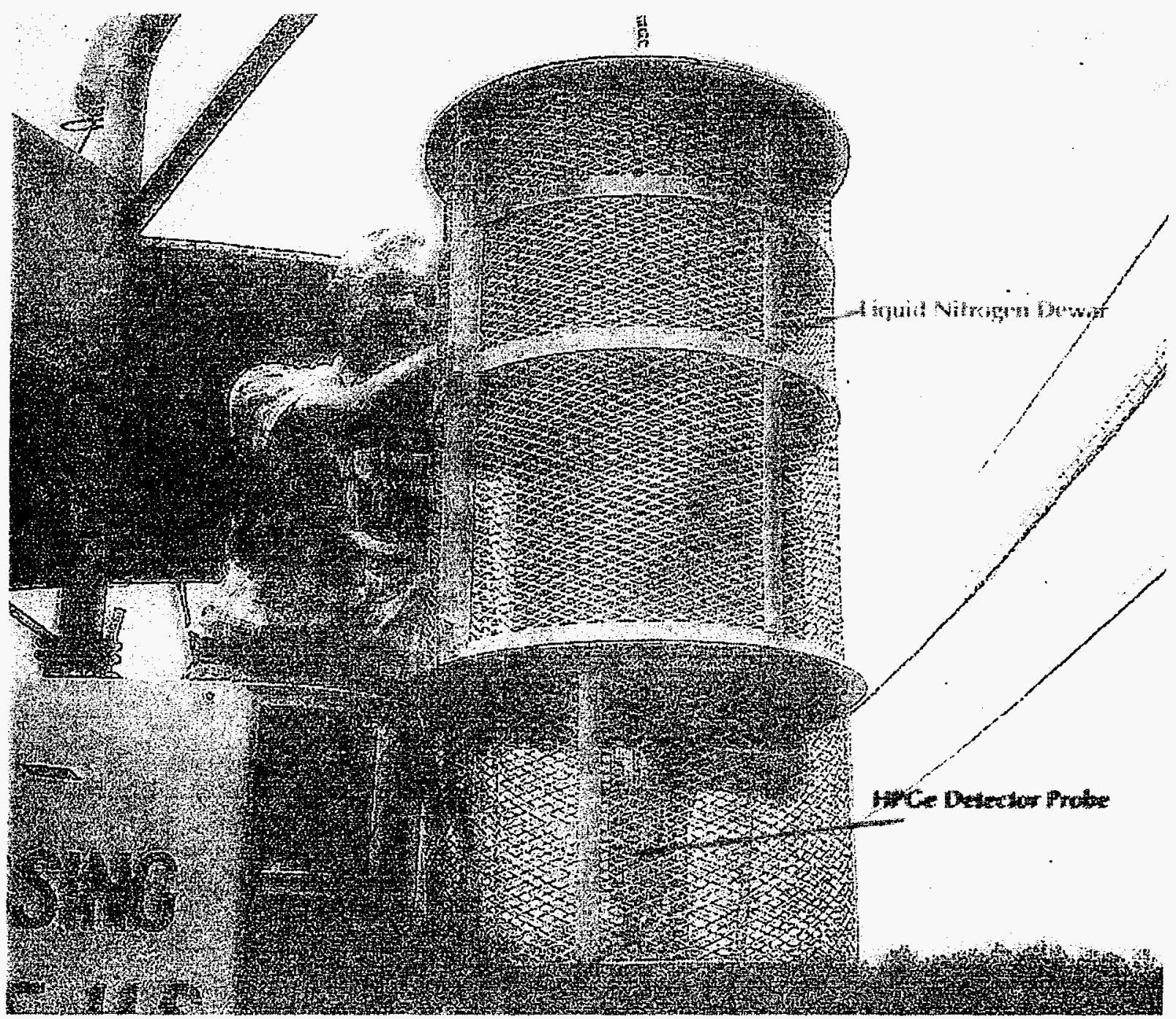

Figure 3. Detector assembly unit with HPGe Detector Probe and Liquid Nitrogen Dewar 


\section{Cs137 Underwater (cpm) \\ - 0-10 \\ - 11.20 \\ - 21.40 \\ - 41-80 \\ $81-160$ \\ 161.320 \\ - 321.640}

$\bigwedge 1985 \operatorname{cs} 137$
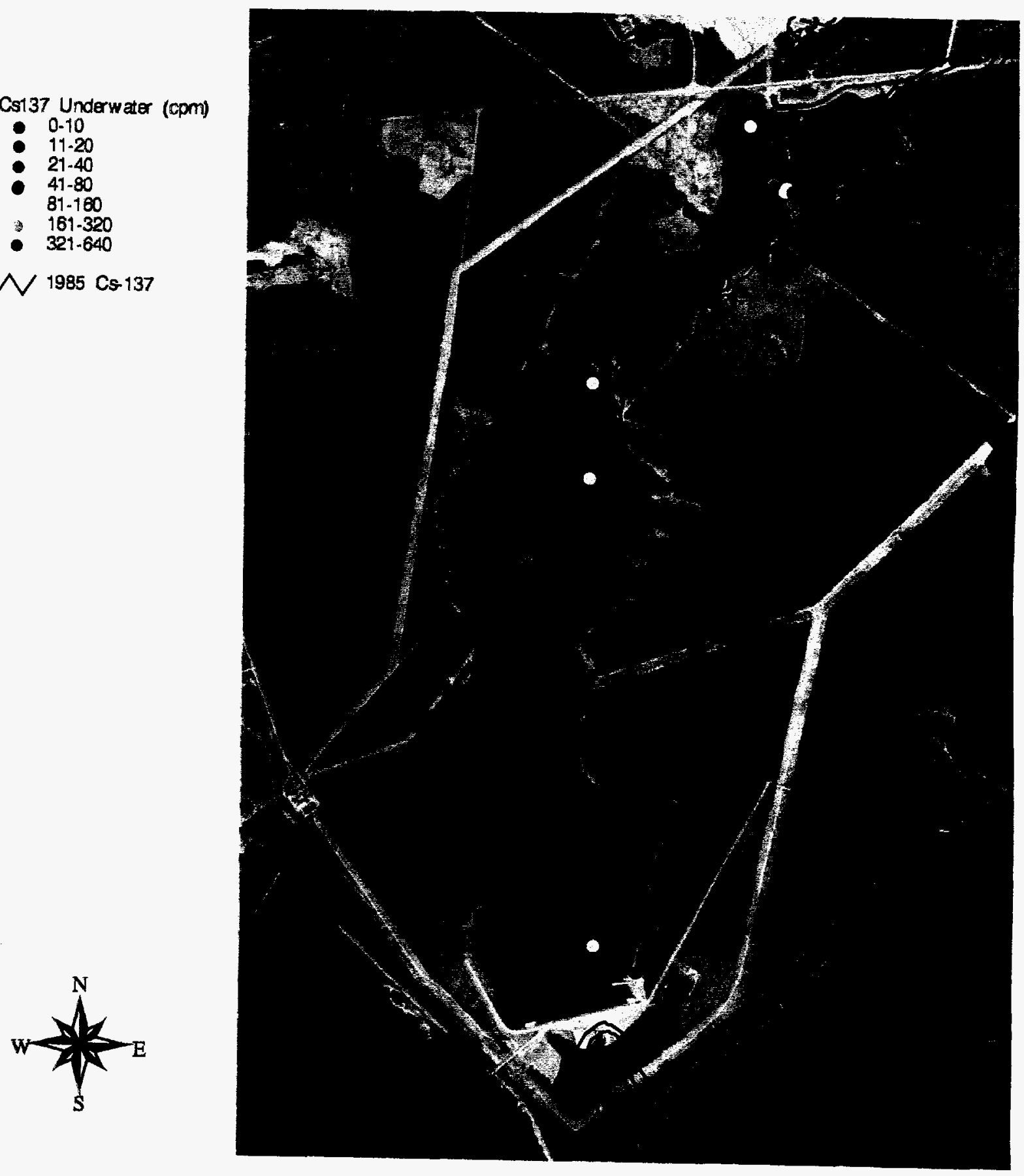

\section{$500 \quad 0 \quad 500 \quad 1000 \quad 1500$ Meters}

Figure 4. 1995 Underwater Detector ${ }^{137} \mathrm{Cs}$ Count Rate Relative to 1985 EG\&G Overflight Generated ${ }^{137} \mathrm{Cs}$ Dose Rate Contours 


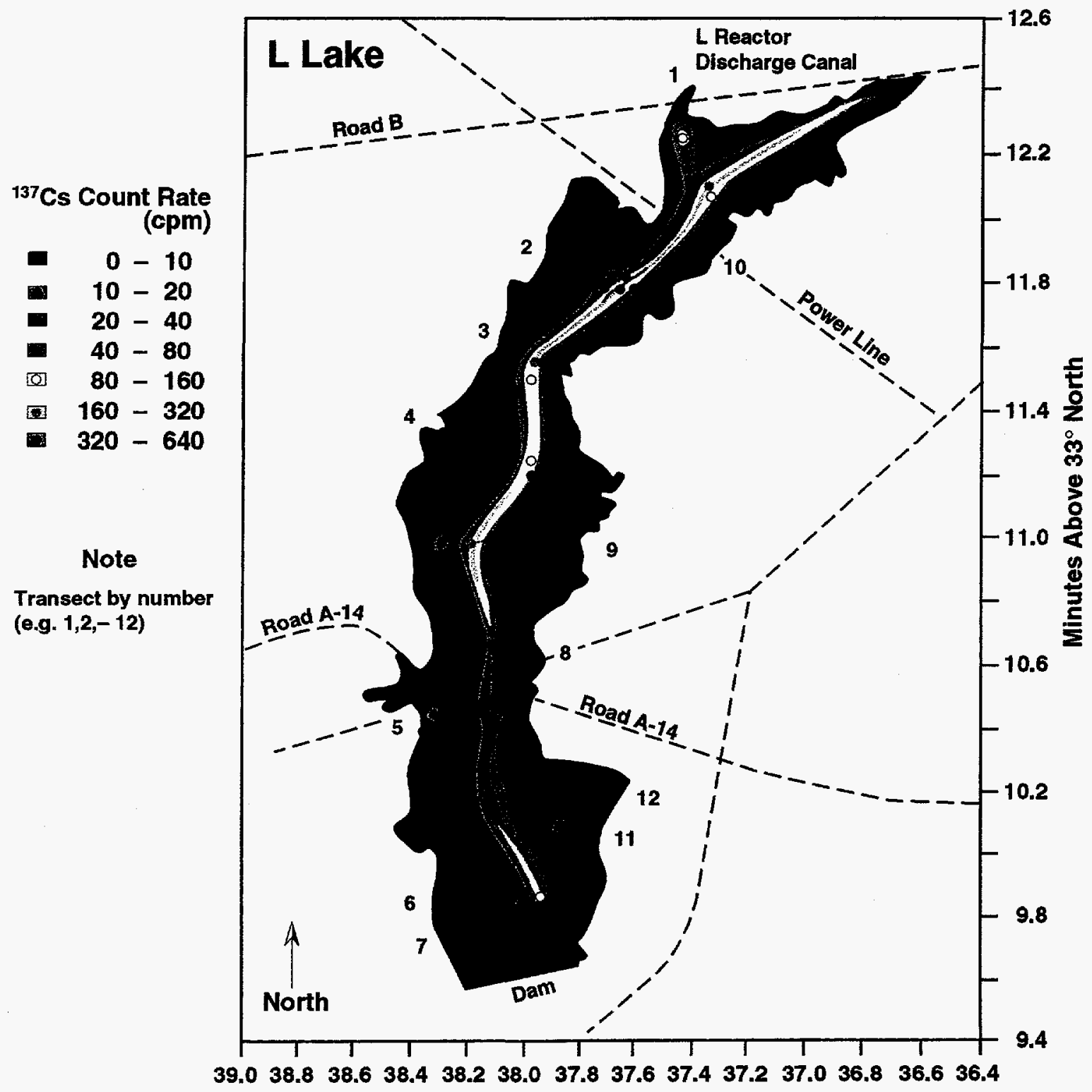

Minutes Above $81^{\circ}$ West

$96 \times 00129.05 \mathrm{a}$. AlL

Figure 5. $\quad{ }^{13 i} \mathrm{Cs}$ Count Rate Contours With Underwater HPGe 


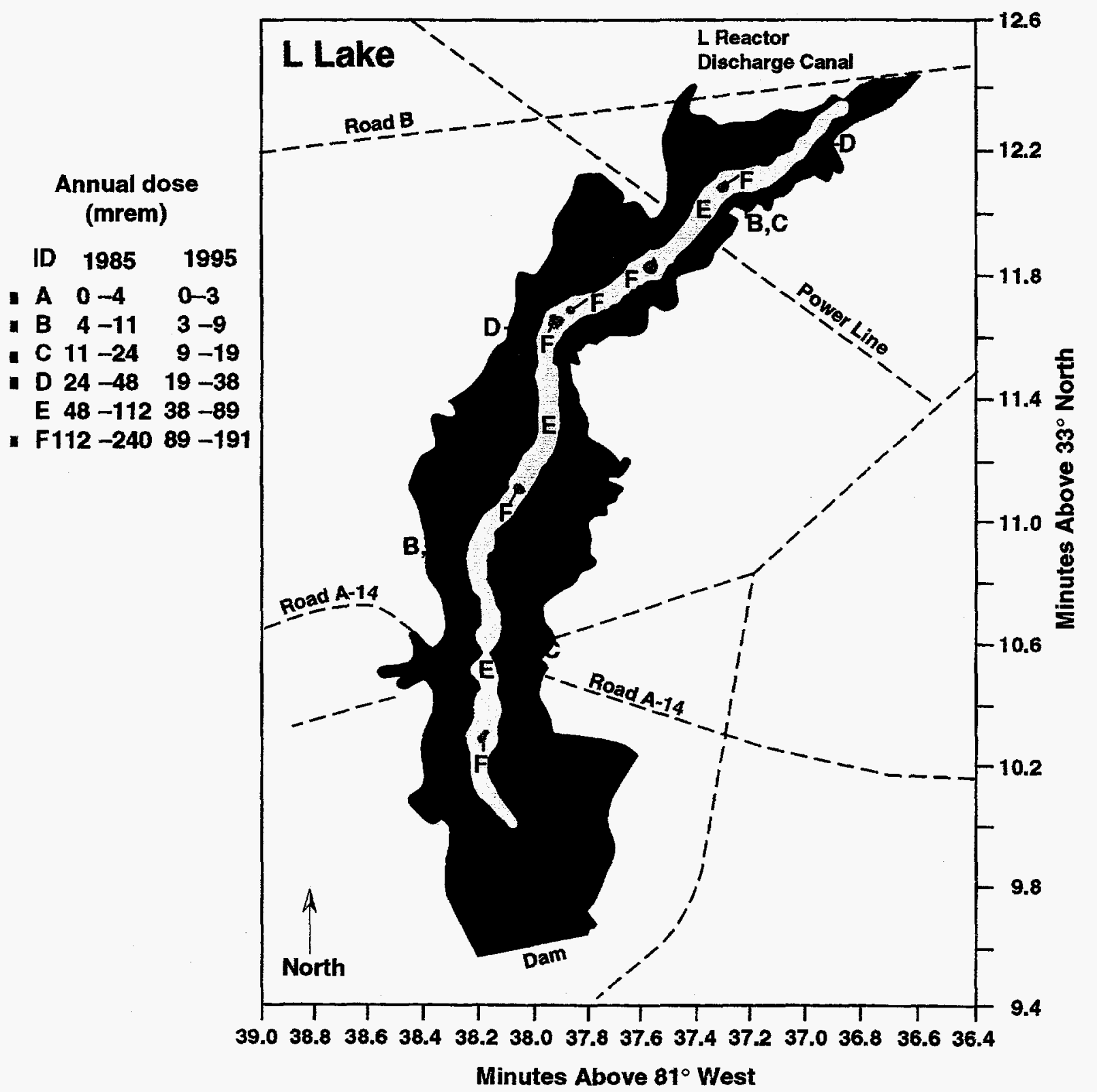

$96 \times 00129.03 a$ AIL

Figure 6. $\quad{ }^{137} \mathrm{Cs}$ Isodose Contours from $1985 \mathrm{EG} \&$ G Overflight NaI Mappings 


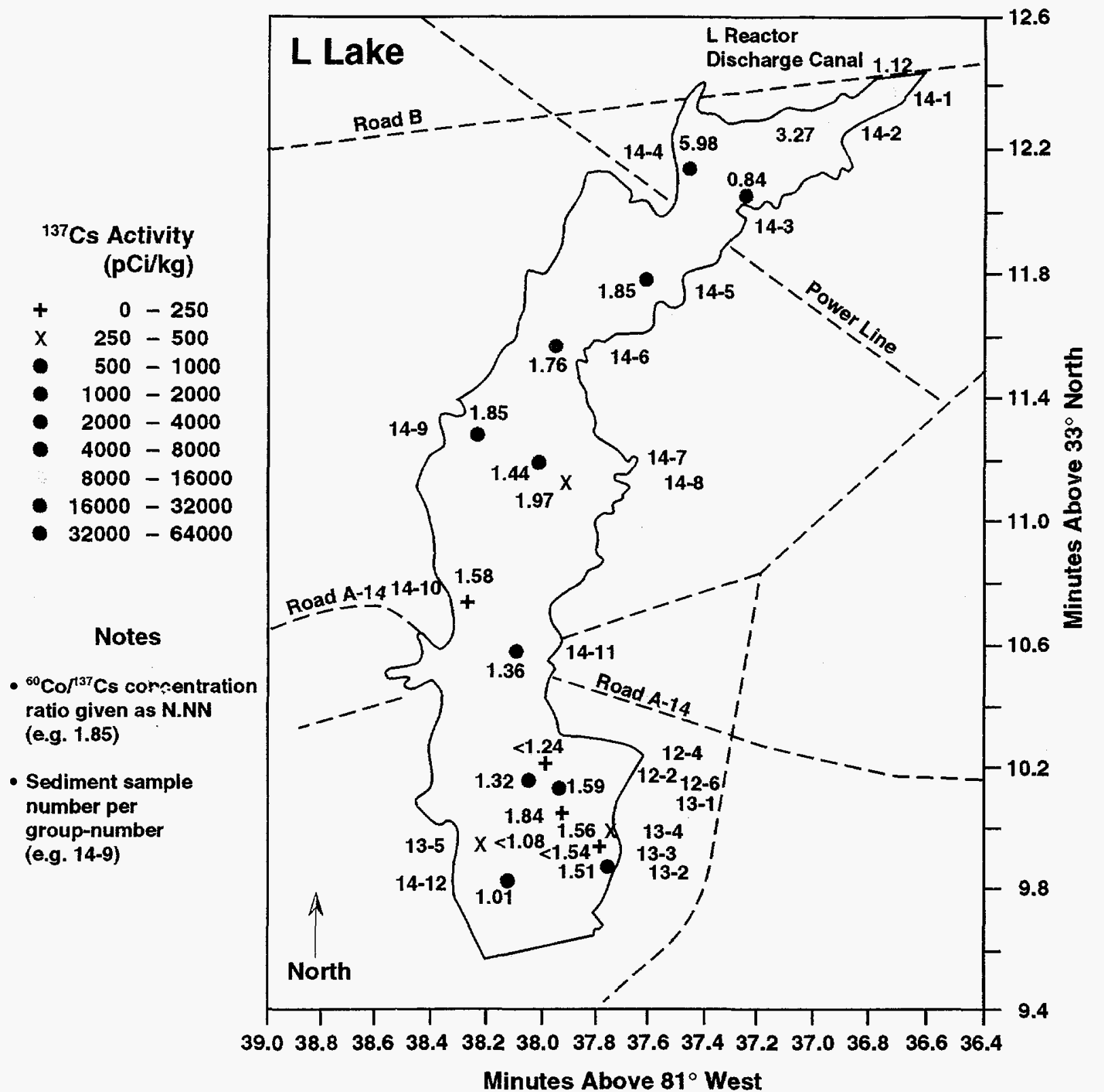

$96 \times 00129.04 a . A I L$

Figure 7. Map of Sediment Radionuclide Concentrations 


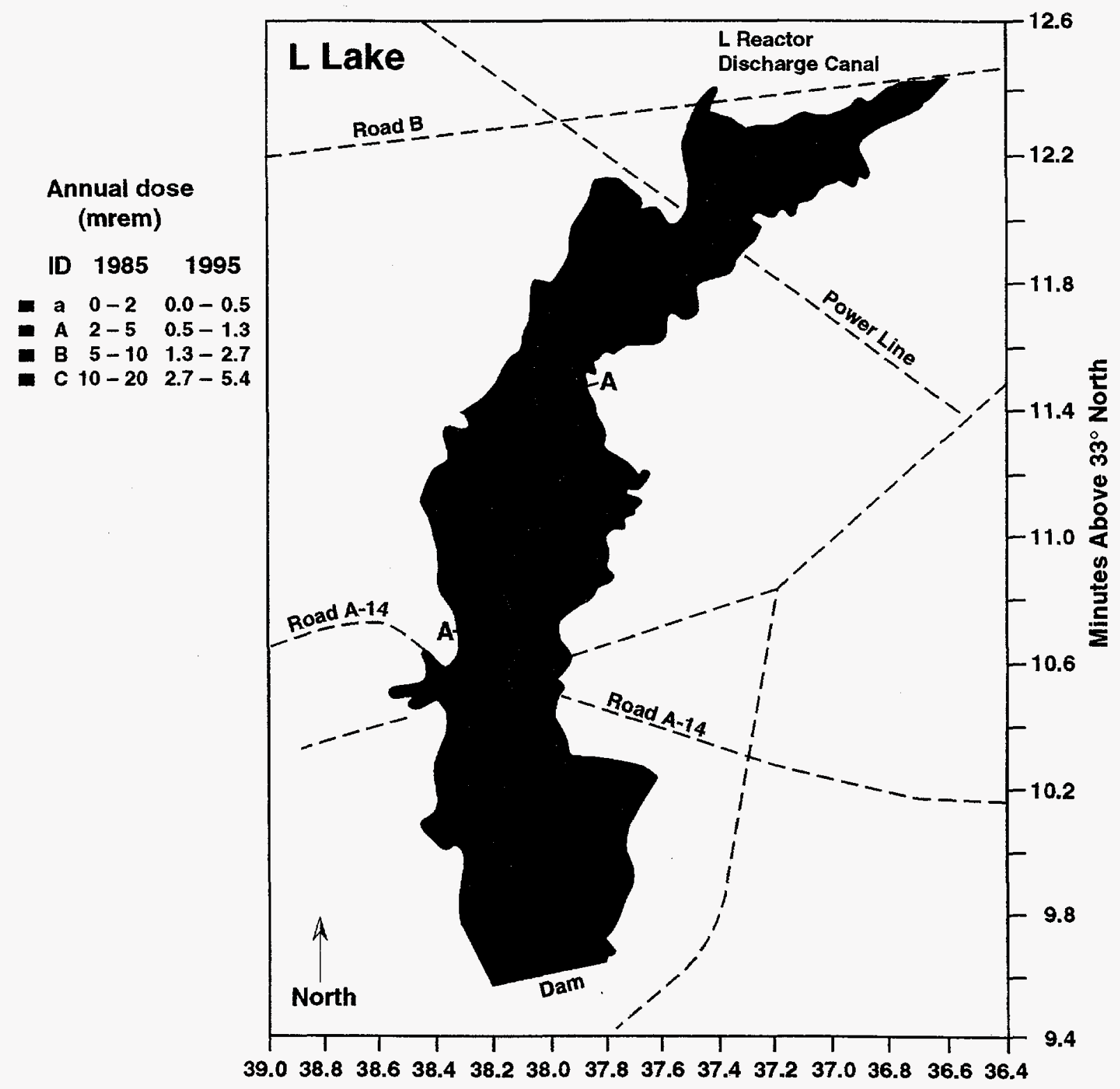

Minutes Above $81^{\circ}$ West

96×00129.02a.AlL

Figure 8. $\quad{ }^{60} \mathrm{Co}$ Isodose Contours from $1985 \mathrm{EG} \& \mathrm{G}$ Overfight NaI Mapping 
Scoping Measurements of Radionuclides in $\mathrm{L}$ Lake with an Underwater HPGe Detector

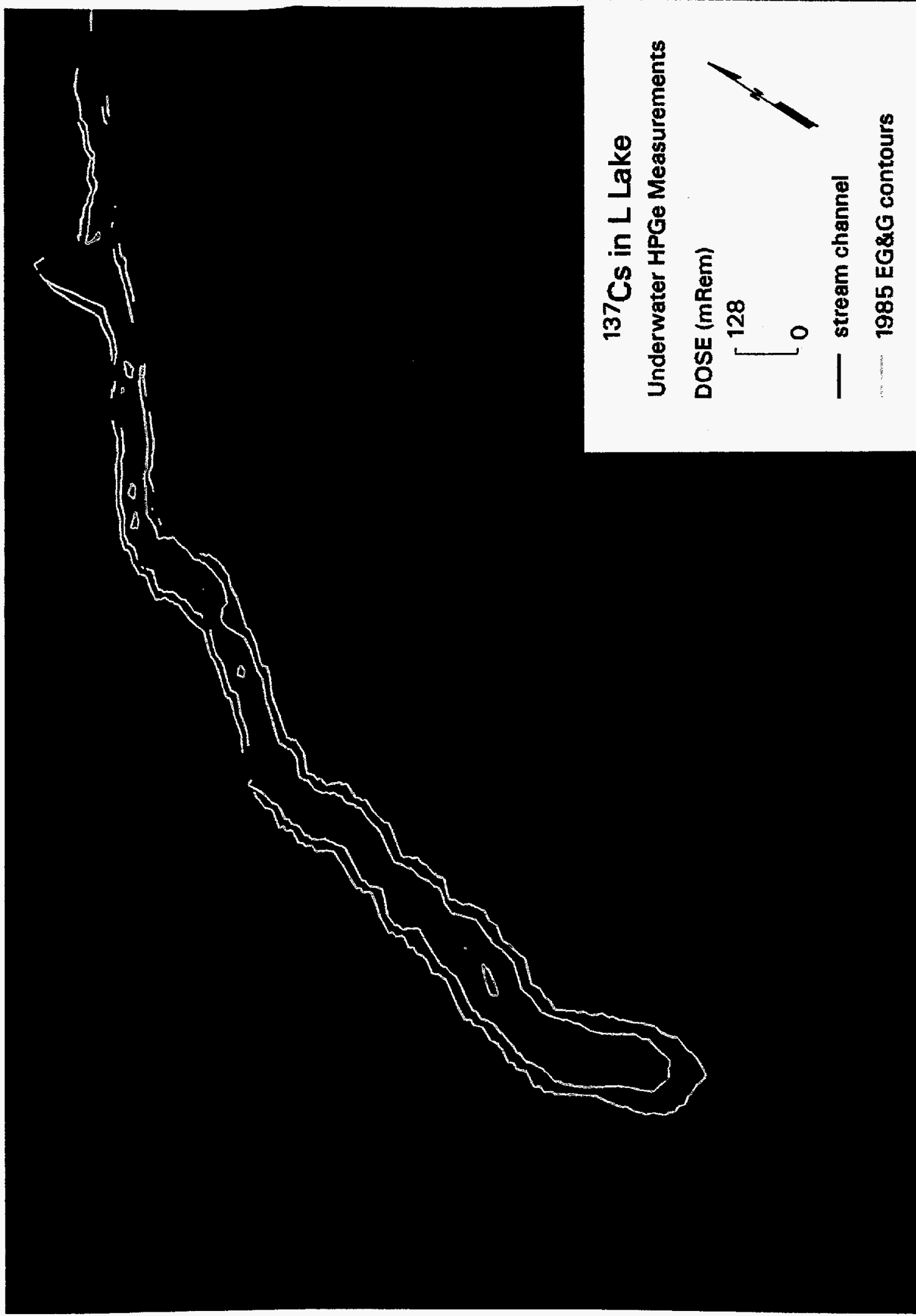

Figure 9. Triangulated Irregular Network Model Projection Of $1995{ }^{137} \mathrm{Cs}$ Distribution 
Scoping Measurements of Radionuclides in L Lake with an Underwater HPGe Detector

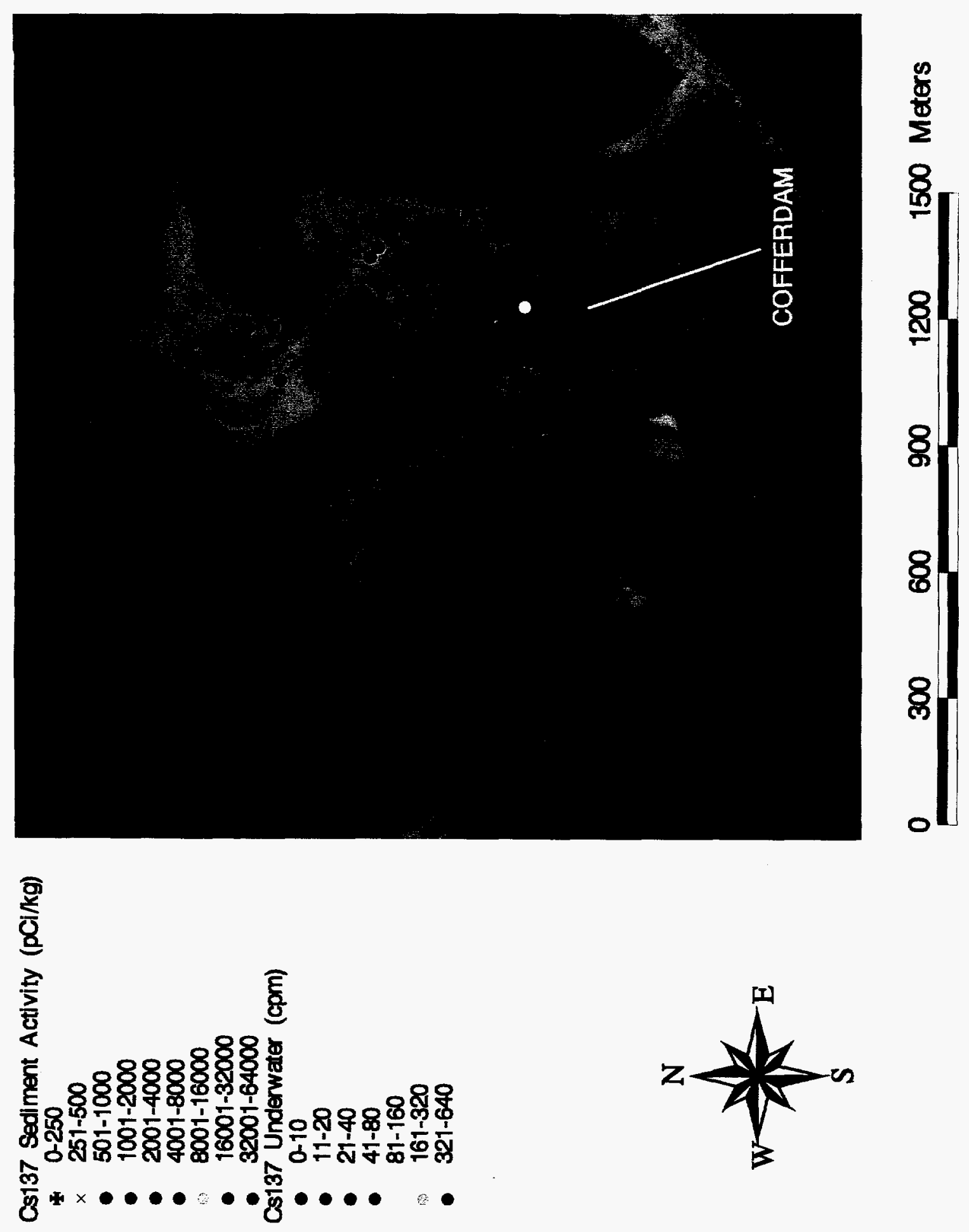

Figure 10. Borrow Pit Examination 


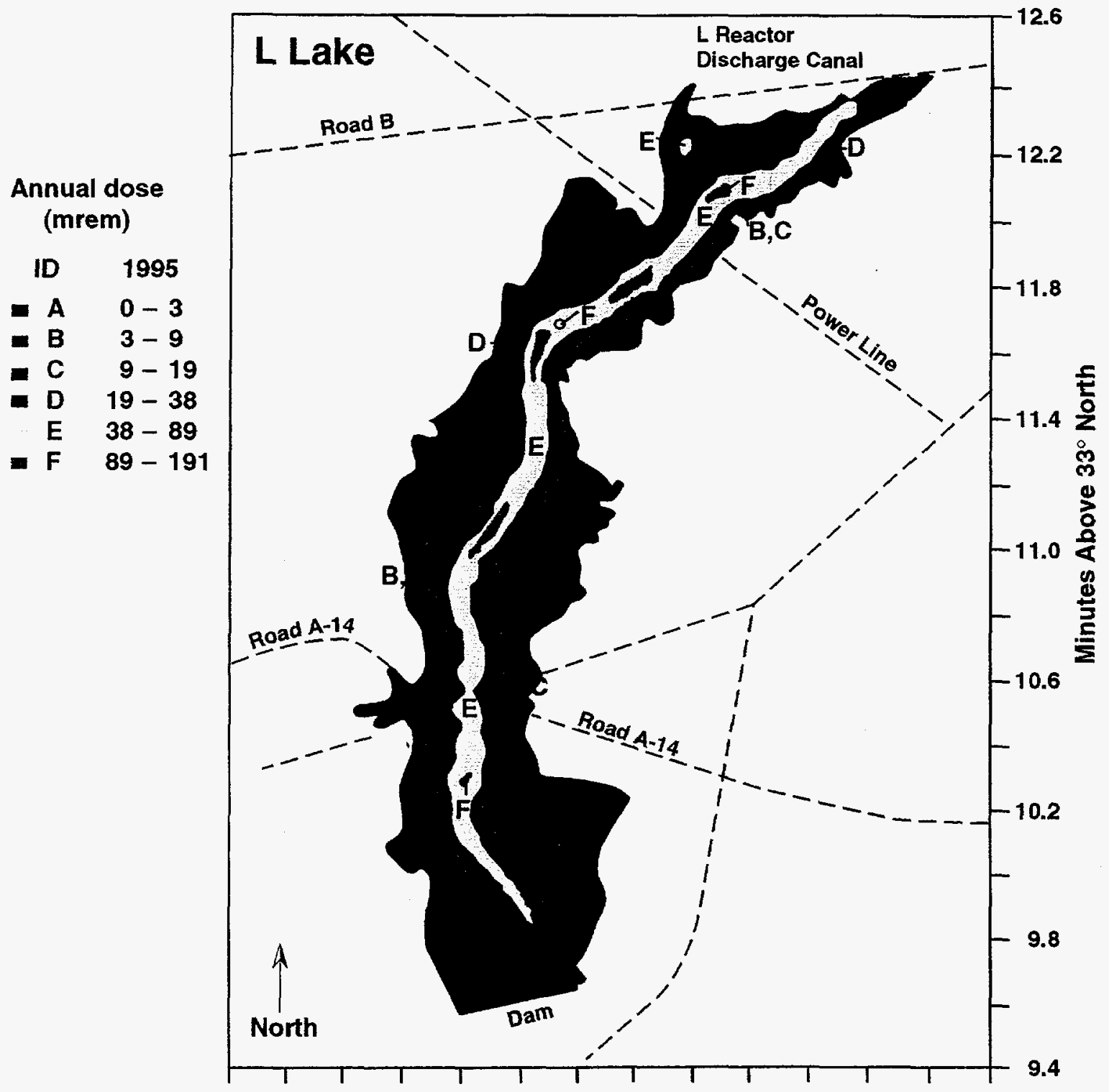

$\begin{array}{lllllllllllllll}39.0 & 38.8 & 38.6 & 38.4 & 38.2 & 38.0 & 37.8 & 37.6 & 37.4 & 37.2 & 37.0 & 36.8 & 36.6 & 36.4\end{array}$

Minutes Above $81^{\circ}$ West

96X00129.01a.AlL

Figure 11. $\quad{ }^{137} \mathrm{Cs}$ Conservative 1995 Isodose Contours 


\section{Appendix A. Data - Underwater HPGe Measurements}

The data for the underwater HPGe measurements on $L$ Lake are summarized in Table A. The data are characterized according to their transects as identified in Figure 5. The table gives the following for each measurement:

- Transect identification

- Date of measurement

- Latitude and longitude

- Lake bottom depth and location

- ${ }^{137} \mathrm{Cs}$ count rate

All entries are essentially self-explanatory; however, some additional comments are in order for the "Depth/Loc" column. The depth in feet may be translated to mean-sea-level (msl) depth by noting that the lake level is about $190 \mathrm{ft}$ msl; more exact levels may be deduced by checking the recorded lake level during the dates of the measurements. The location is given as " $N$ ", " $S$ ", " $E$ ", and " $W$ " to denote relative compass directions relative to the deepest point of a transect; an " $M$ " denotes measurements near the lake middle. Notations " $a$ " and " $\mathrm{b}$ " identify regions where additional dips (relative maximum depths) were observed. 
Scoping Measurements of Radionuclides in L Lake with an Underwater HPGe Detector

Table A. Data - Underwater HPGe Measurements

\begin{tabular}{|c|c|c|c|c|c|}
\hline Transect & Date & $\begin{array}{c}\text { Latitude } \\
\text { Deg'Min'Sec" }\end{array}$ & $\begin{array}{l}\text { Longitude } \\
\text { Deg'Min'Sec" }\end{array}$ & Depth & $\begin{array}{c}\text { Cs-137 Rate } \\
\text { (cpm) }\end{array}$ \\
\hline 1 & $8 / 1 / 95$ & $33^{\circ} 12^{\prime} 13.04^{\prime \prime}$ & $81^{\circ} 37^{\prime} 28.92^{\prime \prime}$ & $3.5 \mathrm{ft} / \mathrm{W}$ & $1+\%-4$ \\
\hline 1 & $8 / 1 / 95$ & $33^{\circ} 12^{\prime} 13.72^{\prime \prime}$ & $81^{\circ} 37^{\prime} 27.10^{\prime \prime}$ & $8 \mathrm{ft} / \mathrm{W}$ & $88+/-11$ \\
\hline 1 & $8 / 1 / 95$ & $33^{\circ} 12^{\prime} 11.01^{\prime \prime}$ & $81^{\circ} 37^{\prime} 25.81^{\prime \prime}$ & $12 \mathrm{fuW}$ & $11+/-5$ \\
\hline 1 & $8 / 1 / 95$ & $33^{\circ} 12^{\prime} 09.32^{\prime \prime}$ & $81^{\circ} 37^{\prime} 23.13^{\prime \prime}$ & $16 \mathrm{ftW}$ & $6+/-4$ \\
\hline 1 & $8 / 1 / 95$ & $33^{\circ} 12^{\prime} 03.63^{\prime \prime}$ & $81^{\circ} 37^{\prime} 22.17^{\prime \prime}$ & $20 \mathrm{ft} / \mathrm{W}$ & $257+/-30$ \\
\hline 1 & $8 / 1 / 95$ & $33^{\circ} 12^{\prime} 02.43^{\prime \prime}$ & $81^{\circ} 37^{\prime} 19.70^{\prime \prime}$ & $24 \mathrm{ft} / \mathrm{W}$ & $122+/-20$ \\
\hline 1 & $8 / 1 / 95$ & $33^{\circ} 12^{\prime} 03.03^{\prime \prime}$ & $81^{\circ} 37^{\prime} 19.37^{\prime \prime}$ & $25 \mathrm{ft} / \mathrm{W}$ & $117+/-24$ \\
\hline 1 & $8 / 1 / 95$ & $33^{\circ} 12^{\prime} 02.31^{\prime \prime}$ & $81^{\circ} 37^{\prime} 18.06^{\prime \prime}$ & $20 \mathrm{ft} / \mathrm{E}$ & $8+1-4$ \\
\hline 1 & $8 / 1 / 95$ & $33^{\circ} 12^{\prime} 02.44^{\prime \prime}$ & $81^{\circ} 37^{\prime} 16.00^{\prime \prime}$ & $12 \mathrm{ft} / \mathrm{E}$ & $-2+1-4$ \\
\hline 2 & $8 / 1 / 95$ & $33^{\circ} 11^{\prime} 49.54^{\prime \prime}$ & $81^{\circ} 37^{\prime} 55.81^{\prime \prime}$ & $3 \mathrm{ft} W$ & $-1+/-3$ \\
\hline 2 & $8 / 1 / 95$ & $33^{\circ} 11^{\prime} 47.11^{\prime \prime}$ & $81^{\circ} 37^{\prime} 54.71^{\prime \prime}$ & $11 \mathrm{ft} / \mathrm{W}$ & $0+/-3$ \\
\hline 2 & $8 / 1 / 95$ & $33^{\circ} 11^{\prime} 46.03^{\prime \prime}$ & $81^{\circ} 37^{\prime} 54.02^{\prime \prime}$ & $20 \mathrm{ft} / \mathrm{W}$ & $4+/-3$ \\
\hline 2 & $8 / 1 / 95$ & $33^{\circ} 11^{\prime} 48.68^{\prime \prime}$ & $81^{\circ} 37^{\prime} 54.07^{\prime \prime}$ & $24 \mathrm{ft} / \mathrm{W}$ & $1+/-3$ \\
\hline 2 & $8 / 1 / 95$ & $33^{\circ} 11^{\prime} 46.30^{\prime \prime}$ & $81^{\circ} 37^{\prime} 43.15^{\prime \prime}$ & $12 \mathrm{ft} / \mathrm{Wa}$ & $7+/-4$ \\
\hline 2 & $8 / 1 / 95$ & $33^{\circ} 11^{\prime} 47.69^{\prime \prime}$ & $81^{\circ} 37^{\prime} 44.24^{\prime \prime}$ & $20 \mathrm{ft} / \mathrm{Wa}$ & $13+1-5$ \\
\hline 2 & $8 / 1 / 95$ & $33^{\circ} 11^{\prime} 46.03^{\prime \prime}$ & $81^{\circ} 37^{\prime} 45.11^{\prime \prime}$ & $30 \mathrm{ft} / \mathrm{Wa}$ & $15+/-5$ \\
\hline 2 & $8 / 1 / 95$ & $33^{\circ} 11^{\prime} 44.37^{\prime \prime}$ & $81^{\circ} 37^{\prime} 42.97^{\prime \prime}$ & $36 \mathrm{fuWa}$ & $2+/-3$ \\
\hline 2 & $8 / 1 / 95$ & $33^{\circ} 11^{\prime} 46.75^{\prime \prime}$ & $81^{\circ} 37^{\prime} 39.29^{\prime \prime}$ & $34 \mathrm{ft} / \mathrm{Wb}$ & $39+/-8$ \\
\hline 2 & $8 / 1 / 95$ & $33^{\circ} 11^{\prime} 45.28^{\prime \prime}$ & $81^{\circ} 37^{\prime} 40.04^{\prime \prime}$ & $30 \mathrm{ft} / \mathrm{Wb}$ & $381+/-35$ \\
\hline 2 & $8 / 1 / 95$ & $33^{\circ} 11^{\prime} 44.35^{\prime \prime}$ & $81^{\circ} 37^{\prime} 38.14^{\prime \prime}$ & $26 \mathrm{ft} / \mathrm{Eb}$ & $48+/-7$ \\
\hline 2 & $8 / 1 / 95$ & $33^{\circ} 11^{\prime} 44.66^{\prime \prime}$ & $81^{\circ} 37^{\prime} 36.68^{\prime \prime}$ & $22 \mathrm{ft} / \mathrm{Eb}$ & $8 \div /-3$ \\
\hline 2 & $8 / 1 / 95$ & $33^{\circ} 11^{\prime} 43.54^{\prime \prime}$ & $81^{\circ} 37^{\prime} 35.33^{\prime \prime}$ & $16 \mathrm{ft} / \mathrm{Eb}$ & $5+/-3$ \\
\hline 2 & $8 / 1 / 95$ & $33^{\circ} 11^{\prime} 43.76^{\prime \prime}$ & $81^{\circ} 37^{\prime} 33.62^{\prime \prime}$ & $8 \mathrm{ft} / \mathrm{Eb}$ & $8+1-3$ \\
\hline 3 & $8 / 1 / 95$ & $33^{\circ} 11^{\prime} 33.04^{\prime \prime}$ & $81^{\circ} 37^{\prime} 54.35^{\prime \prime}$ & $4 \mathrm{ft} / \mathrm{E}$ & $-2+/-3$ \\
\hline 3 & $8 / 1 / 95$ & $33^{\circ} 11^{\prime} 31.87^{\prime \prime}$ & $81^{\circ} 37^{\prime} 56.61^{\prime \prime}$ & $12 \mathrm{ft} / \mathrm{E}$ & $2+/-1$ \\
\hline 3 & $8 / 7 / 95$ & $33^{\circ} 11^{\prime} 31.10^{\prime \prime}$ & $81^{\circ} 37^{\prime} 57.86^{\prime \prime}$ & $24 \mathrm{ft} / \mathrm{E}$ & $12+/-4$ \\
\hline 3 & $8 / 1 / 95$ & $33^{\circ} 11^{\prime} 30.78^{\prime \prime}$ & $81^{\circ} 37^{\prime} 58.78^{\prime \prime}$ & $38 \mathrm{ft} / \mathrm{E}$ & $260+/-16$ \\
\hline 3 & $8 / 1 / 95$ & $33^{\circ} 11^{\prime} 28.38^{\prime \prime}$ & $81^{\circ} 37^{\prime} 58.59^{\prime \prime}$ & $42 \mathrm{ft} / \mathrm{E}$ & $115+/-12$ \\
\hline 3 & $8 / 1 / 95$ & $33^{\circ} 11^{\prime} 25.82^{\prime \prime}$ & $81^{\circ} 38^{\prime} 01.10^{\prime \prime}$ & $32 \mathrm{ft} / \mathrm{W}$ & $19+/-5$ \\
\hline 3 & $8 / 7 / 95$ & $33^{\circ} 11^{\prime} 30.91^{\prime \prime}$ & $81^{\circ} 38^{\prime} 03.62^{\prime \prime}$ & $18 \mathrm{ft} / \mathrm{W}$ & $0+1-2$ \\
\hline 3 & $8 / 1 / 95$ & $33^{\circ} 11^{\prime} 33.52^{\prime \prime}$ & $81^{\circ} 38^{\prime} 05.21^{\prime \prime}$ & $10 \mathrm{ft} / \mathrm{W}$ & $3+/-3$ \\
\hline 3 & $8 / 1 / 95$ & $33^{\circ} 11^{\prime} 30.72^{\prime \prime}$ & $81^{\circ} 38^{\prime} 03.43^{\prime \prime}$ & $24 \mathrm{fOW}$ & $4+/-2$ \\
\hline
\end{tabular}


Scoping Measurements of Radionuclides in L Lake with an Underwater HPGe Detector

Table A. Data-Underwater HPGe Measurements (continued)

\begin{tabular}{|c|c|c|c|c|c|}
\hline Transect & Date & $\begin{array}{c}\text { Latitude } \\
\text { Deg }^{\circ} \mathrm{Min}^{\prime} \mathrm{Sec}^{\prime \prime}\end{array}$ & $\begin{array}{c}\text { Longitude } \\
\text { Deg }{ }^{\circ} \text { Min' Sec }^{\prime \prime}\end{array}$ & Depth & $\begin{array}{c}\text { Cs-137 Rate } \\
\text { (cpm) }\end{array}$ \\
\hline 4 & $8 / 1 / 95$ & $33^{\circ} 11^{\prime} 10.98^{\prime \prime}$ & $81^{\circ} 37^{\prime} 45.65^{\prime \prime}$ & $8 \mathrm{ft} / \mathrm{E}$ & $2+/-1$ \\
\hline 4 & $8 / 1 / 95$ & $33^{\circ} 11^{\prime} 08.61^{\prime \prime}$ & $81^{\circ} 37^{\prime} 52.93^{\prime \prime}$ & $11 \mathrm{ft} / \mathrm{E}$ & $4+/-3$ \\
\hline 4 & $8 / 1 / 95$ & $33^{\circ} 11^{\prime} 09.32^{\prime \prime}$ & $81^{\circ} 37^{\prime} 54.99^{\prime \prime}$ & $21 \mathrm{ft} / \mathrm{E}$ & $7+/-3$ \\
\hline 4 & $8 / 1 / 95$ & $33^{\circ} 11^{\prime} 12.20^{\prime \prime}$ & $81^{\circ} 37^{\prime} 57.47^{\prime \prime}$ & $30 \mathrm{ft} / \mathrm{E}$ & $14+/-4$ \\
\hline 4 & $8 / 1 / 95$ & $33^{\circ} 11^{\prime} 11.70^{\prime \prime}$ & $81^{\circ} 37^{\prime} 58.86^{\prime \prime}$ & $45 \mathrm{ft} / \mathrm{E}$ & $150+/-12$ \\
\hline 4 & $8 / 1 / 95$ & $33^{\circ} 11^{\prime} 07.73^{\prime \prime}$ & $81^{\circ} 37^{\prime} 58.32^{\prime \prime}$ & $39 \mathrm{ft} / \mathrm{E}$ & $9+/-3$ \\
\hline 4 & $8 / 1 / 95$ & $33^{\circ} 11^{\prime} 14.88^{\prime \prime}$ & $81^{\circ} 38^{\prime} 04.22^{\prime \prime}$ & $37 \mathrm{ft} / \mathrm{W}$ & $5+/-5$ \\
\hline 4 & $8 / 7 / 95$ & $33^{\circ} 11^{\prime} 14.18^{\prime \prime}$ & $81^{\circ} 38^{\prime} 06.71^{\prime \prime}$ & $30 \mathrm{ft} / \mathrm{W}$ & $4+/-4$ \\
\hline 4 & $8 / 1 / 95$ & $33^{\circ} 11^{\prime} 14.29^{\prime \prime}$ & $81^{\circ} 38^{\prime} 15.65^{\prime \prime}$ & $29 \mathrm{ft} / \mathrm{W}$ & $2+/-3$ \\
\hline 4 & $8 / 1 / 95$ & $33^{\circ} 11^{\prime} 18.75^{\prime \prime}$ & $81^{\circ} 38^{\prime} 17.65^{\prime \prime}$ & $16 \mathrm{ft} / \mathrm{W}$ & $4+/-4$ \\
\hline 5 & $8 / 2 / 95$ & $33^{\circ} 10^{\prime} 21.18^{\prime \prime}$ & $81^{\circ} 38^{\prime} 21.36^{\prime \prime}$ & $14 \mathrm{ft} / \mathrm{W}$ & $2+/-3$ \\
\hline 5 & $8 / 2 / 95$ & $33^{\circ} 10^{\prime} 24.88^{\prime \prime}$ & $81^{\circ} 38^{\prime} 18.98^{\prime \prime}$ & $24 \mathrm{ft} / \mathrm{W}$ & $12+/-4$ \\
\hline 5 & $8 / 2 / 95$ & $33^{\circ} 10^{\prime} 20.00^{\prime \prime}$ & $81^{\circ} 38^{\prime} 09.06^{\prime \prime}$ & $32 \mathrm{ftW}$ & $0+/-2$ \\
\hline 5 & $8 / 2 / 95$ & $33^{\circ} 10^{\prime} 25.62^{\prime \prime}$ & $81^{\circ} 38^{\prime} 17.55^{\prime \prime}$ & $40 \mathrm{ft} / \mathrm{W}$ & $1+/-2$ \\
\hline 5 & $8 / 2 / 95$ & $33^{\circ} 10^{\prime} 26.35^{\prime \prime}$ & $81^{\circ} 38^{\prime} 16.69^{\prime \prime}$ & $45 \mathrm{ft} / \mathrm{W}$ & $7+/-3$ \\
\hline 5 & $8 / 2 / 95$ & $33^{\circ} 10^{\prime} 24.34^{\prime \prime}$ & $81^{\circ} 38^{\prime} 14.00^{\prime \prime}$ & $51 \mathrm{fuW}$ & $3+/-3$ \\
\hline 5 & $8 / 2 / 95$ & $33^{\circ} 10^{\prime} 21.45^{\prime \prime}$ & $81^{\circ} 38^{\prime} 07.69^{\prime \prime}$ & $55 \mathrm{ft} / \mathrm{W}$ & $6+/-3$ \\
\hline 5 & $8 / 2 / 95$ & $33^{\circ} 10^{\prime} 25.48^{\prime \prime}$ & $81^{\circ} 38^{\prime} 11.16^{\prime \prime}$ & $56 \mathrm{ft} / \mathrm{W}$ & $3+/-2$ \\
\hline 5 & $8 / 2 / 95$ & $33^{\circ} 10^{\prime} 24.21^{\prime \prime}$ & $81^{\circ} 38^{\prime} 09.49^{\prime \prime}$ & $59 \mathrm{ft} / \mathrm{W}$ & $29+1-6$ \\
\hline 5 & $8 / 2 / 95$ & $33^{\circ} 10^{\prime} 22.84^{\prime \prime}$ & $81^{\circ} 38^{\prime} 07.84^{\prime \prime}$ & $56 \mathrm{ft} / \mathrm{E}$ & $49+1-7$ \\
\hline 5 & $8 / 2 / 95$ & $33^{\circ} 10^{\prime} 22.00^{\prime \prime}$ & $81^{\circ} 38^{\prime} 02.54^{\prime \prime}$ & $36 \mathrm{ft} / \mathrm{E}$ & $3+/-2$ \\
\hline 5 & $8 / 2 / 95$ & $33^{\circ} 10^{\prime} 24.75^{\prime \prime}$ & $81^{\circ} 38^{\circ} 08.42^{\mu}$ & $54 \mathrm{ft} / \mathrm{M}$ & $5+/-3$ \\
\hline 5 & $8 / 2 / 95$ & $33^{\circ} 10^{\prime} 25.17^{\prime \prime}$ & $81^{\circ} 38^{\prime} 03.94^{\prime \prime}$ & $36 \mathrm{ft} / \mathrm{Ea}$ & $11+/-4$ \\
\hline 5 & $8 / 2 / 95$ & $33^{\circ} 10^{\prime} 25.80^{\prime \prime}$ & $81^{\circ} 38^{\prime} 06.20^{\prime \prime}$ & $44 \mathrm{ft} / \mathrm{Ea}$ & $5+/-3$ \\
\hline 5 & $8 / 2 / 95$ & $33^{\circ} 10^{\prime} 27.10^{\prime \prime}$ & $81^{\circ} 38^{\prime} 03.50^{t \prime}$ & $12 \mathrm{ft} / \mathrm{E}$ & $7+/-3$ \\
\hline 6 & $8 / 2 / 95$ & $33^{\circ} 09^{\prime} 48.19^{\prime \prime}$ & $81^{\circ} 38^{\prime} 17.61^{\prime \prime}$ & $6 \mathrm{ft} / \mathrm{W}$ & $1+/-2$ \\
\hline 6 & $8 / 7 / 95$ & $33^{\circ} 09^{\prime} 49.31^{\prime \prime}$ & $81^{\circ} 38^{\prime} 09.98^{\prime \prime}$ & $15 \mathrm{ft} / \mathrm{W}$ & $3+/-2$ \\
\hline 6 & $8 / 7 / 95$ & $33^{\circ} 09^{\prime} 49.36^{4}$ & $81^{\circ} 38^{\prime} 05.30^{\prime \prime}$ & $36 \mathrm{fth}$ & $4+/-3$ \\
\hline 6 & $8 / 7 / 95$ & $33^{\circ} 09^{\prime} 49.66^{\prime \prime}$ & $81^{\circ} 38^{\prime} 01.36^{\prime \prime}$ & $45 \mathrm{ft} / \mathrm{W}$ & $2+/-4$ \\
\hline 6 & $8 / 7 / 95$ & $33^{\circ} 09^{\prime} 50.05^{\prime \prime}$ & $81^{\circ} 37^{\prime} 56.46^{\prime \prime}$ & $68 \mathrm{ft} W$ & $142+/-13$ \\
\hline 6 & $8 / 7 / 95$ & $33^{\circ} 09^{\prime} 48.96^{\prime \prime}$ & $81^{\circ} 38^{\prime} 03.14^{\prime \prime}$ & $63 \mathrm{ft} / \mathrm{W}$ & $15+/-4$ \\
\hline 6 & $8 / 7 / 95$ & $33^{\circ} 09^{\prime} 47.32^{\prime \prime}$ & $81^{\circ} 37^{\prime} 55.30^{\prime \prime}$ & $54 \mathrm{ft} / \mathrm{E}$ & $2+/-2$ \\
\hline 6 & $8 / 7 / 95$ & $33^{\circ} 09^{\prime} 45.15^{\prime \prime}$ & $81^{\circ} 37^{\prime} 51.62^{\prime \prime}$ & $23 \mathrm{ft} / \mathrm{E}$ & $0+/-4$ \\
\hline 6 & $8 / 7 / 95$ & $33^{\circ} 09^{\prime} 45.59^{\prime \prime}$ & $81^{\circ} 37^{\prime} 47.54^{\prime \prime}$ & $15 \mathrm{ft} / \mathrm{E}$ & $3+1-3$ \\
\hline 6 & $8 / 7 / 95$ & $33^{\circ} 09^{\circ} 49.47^{\prime \prime}$ & $81^{\circ} 37^{\prime} 45.81^{\prime \prime}$ & $4 \mathrm{ft} / \mathrm{E}$ & $2+1-3$ \\
\hline
\end{tabular}


Scoping Measurements of Radionuclides in L Lake with an Underwater HPGe Detector

Table A. Data-Underwater HPGe Measurements (continued)

\begin{tabular}{|c|c|c|c|c|c|}
\hline Transect & Date & $\begin{array}{c}\text { Latitude } \\
\text { Deg'Min'Sec" }\end{array}$ & $\begin{array}{l}\text { Longitude } \\
\text { Deg Min'Sec" }\end{array}$ & Depth & $\begin{array}{l}\text { Cs-137 } \\
(\mathrm{cpm})\end{array}$ \\
\hline 7 & $8 / 2 / 95$ & $33^{\circ} 09^{1} 42.66^{11}$ & $81^{\circ} 38^{\prime} 03.36^{\prime \prime}$ & $48 \mathrm{ft} / \mathrm{M}$ & $5+1-3$ \\
\hline 7 & $8 / 2 / 95$ & $33^{\circ} 09^{\prime} 41.95^{\prime \prime}$ & $81^{\circ} 38^{\prime} 01.55^{\prime \prime}$ & $45 \mathrm{ft} / \mathrm{W}$ & $6+/-4$ \\
\hline 7 & $8 / 2 / 95$ & $33^{\circ} 09^{\prime} 43.68^{\prime \prime}$ & $81^{\circ} 38^{\prime} 01.56^{\prime \prime}$ & $68 \mathrm{ft} / \mathrm{W}$ & $5+/-3$ \\
\hline 7 & $8 / 2 / 95$ & $33^{\circ} 09^{\prime} 44.38^{\prime \prime}$ & $81^{\circ} 37^{\prime} 58.41^{\prime \prime}$ & $68 \mathrm{ft} / \mathrm{E}$ & $6+/-3$ \\
\hline 7 & $8 / 2 / 95$ & $33^{\circ} 09^{\prime} 42.74^{\prime \prime}$ & $81^{\circ} 37^{\prime} 56.23^{\prime \prime}$ & 70ft/E & $3+/-4$ \\
\hline 8 & $8 / 7 / 95$ & $33^{\circ} 10^{\prime} 35.80^{\prime \prime}$ & $81^{\circ} 38^{\prime} 07.35^{\prime \prime}$ & $42 \mathrm{ft} / \mathrm{E}$ & $12+/-4$ \\
\hline 8 & $8 / 7 / 95$ & $33^{\circ} 10^{\prime} 34.80^{\prime \prime}$ & $81^{\circ} 38^{\prime} 09.86^{\prime \prime}$ & $48 \mathrm{ft} / \mathrm{E}$ & $7+/-3$ \\
\hline 8 & $8 / 7 / 95$ & $33^{\circ} 10^{\prime} 32.57^{\prime \prime}$ & $81^{\circ} 38^{\prime} 10.14^{\prime \prime}$ & $57 \mathrm{ft} / \mathrm{E}$ & $9+/-5$ \\
\hline 8 & $8 / 7 / 95$ & $33^{\circ} 10^{\prime} 33.85^{\prime \prime}$ & $81^{\circ} 38^{\prime} 15.66^{\prime \prime}$ & $47 \mathrm{ft} / \mathrm{E}$ & $8+/-4$ \\
\hline 8 & $8 / 7 / 95$ & $33^{\circ} 10^{\prime} 32.85^{\prime \prime}$ & $81^{\circ} 38^{\prime} 07.08^{\prime \prime}$ & $51 \mathrm{ft} / \mathrm{E}$ & $7+/-5$ \\
\hline 9 & $8 / 7 / 95$ & $33^{\circ} 70^{\prime} 56.73^{\prime \prime}$ & $81^{\circ} 38^{\prime} 18.17^{\prime \prime}$ & $32 \mathrm{ft} / \mathrm{W}$ & $12+/-4$ \\
\hline 9 & $8 / 7 / 95$ & $33^{\circ} 10^{\prime} 54.18^{\prime \prime}$ & $81^{\circ} 38^{\prime} 13.42^{\prime \prime}$ & $47 \mathrm{ftM}$ & $8+1-4$ \\
\hline 9 & $8 / 7 / 95$ & $33^{\circ} 10^{\prime} 57.29^{\prime \prime}$ & $87^{\circ} 38^{\prime} 11.68^{\prime \prime}$ & $49 \mathrm{ft} W$ & $194+/-19$ \\
\hline 9 & $8 / 7 / 95$ & $33^{\circ} 10^{\prime} 57.75^{\prime \prime}$ & $81^{\circ} 38^{\prime} 05.85^{\prime \prime}$ & $27 \mathrm{ft} / \mathrm{E}$ & $10+1-3$ \\
\hline 10 & $8 / 7 / 95$ & $33^{\circ} 11^{\prime} 52.34^{\prime \prime}$ & $87^{\circ} 37^{\prime} 21.37^{\prime \prime}$ & $5 \mathrm{ft} / \mathrm{S}$ & $0+/-3$ \\
\hline 10 & $8 / 7 / 95$ & $33^{\circ} 11^{\prime} 53.56^{\prime \prime}$ & $81^{\circ} 37^{\prime} 19.93^{\prime \prime}$ & $4 \mathrm{ft} / \mathrm{N}$ & $3+/-2$ \\
\hline 10 & $8 / 7 / 95$ & $33^{\circ} 11^{\prime} 55.43^{\prime \prime}$ & $81^{\circ} 37^{\prime} 20.24^{\prime \prime}$ & $8 \mathrm{ft} / \mathrm{N}$ & $6+/-3$ \\
\hline 10 & $8 / 7 / 95$ & $33^{\circ} 11^{\prime} 53.58^{\prime \prime}$ & $81^{\circ} 37^{\prime} 21.36^{\prime \prime}$ & $12 \mathrm{ft} / \mathrm{s}$ & $0+/-3$ \\
\hline 11 & $8 / 7 / 95$ & $33^{\circ} 10^{\prime} 01.88^{\prime \prime}$ & $81^{\circ} 37^{\prime} 51.97^{\prime \prime}$ & $21 \mathrm{ft} / \mathrm{E}$ & $13+/-4$ \\
\hline 11 & $8 / 7 / 95$ & $33^{\circ} 10^{\prime} 01.26^{\prime \prime}$ & $81^{\circ} 37^{\prime} 51.04^{\prime \prime}$ & $13 \mathrm{ft} / \mathrm{E}$ & $8+/-4$ \\
\hline 11 & $8 / 7 / 95$ & $33^{\circ} 10^{\prime} 02.17^{\prime \prime}$ & $81^{\circ} 37^{\prime} 48.51^{\prime \prime}$ & $10 \mathrm{ft} / \mathrm{E}$ & $0+/-2$ \\
\hline 11 & $8 / 7 / 95$ & $33^{\circ} 09^{\prime} 58.99^{\prime \prime}$ & $81^{\circ} 37^{\prime} 49.92^{\prime \prime}$ & $23 \mathrm{ft} / \mathrm{E}$ & $2+/-4$ \\
\hline 11 & $8 / 7 / 95$ & $33^{\circ} 09^{\prime} 53.82^{\prime \prime}$ & $81^{\circ} 37^{\prime} 48.97^{\prime \prime}$ & $18 \mathrm{ft} / \mathrm{E}$ & $1+/-1$ \\
\hline 12 & $8 / 9 / 95$ & $33^{\circ} 10^{\prime} 08.94^{\prime \prime}$ & $81^{\circ} 38^{\prime} 02.49^{\prime \prime}$ & $25 \mathrm{ft} / \mathrm{M}$ & $-1+/-2$ \\
\hline 12 & $8 / 9 / 95$ & $33^{\circ} 10^{\prime} 08.65^{\prime \prime}$ & $81^{\circ} 38^{\prime} 03.25^{\prime 3}$ & $30 \mathrm{ft} / \mathrm{M}$ & $13+/-5$ \\
\hline 12 & $8 / 9 / 95$ & $33^{\circ} 10^{\prime} 11.77^{\prime \prime}$ & $81^{\circ} 38^{\circ} 04.25^{\prime \prime}$ & $20 \mathrm{ft} / \mathrm{M}$ & $-4+/-3$ \\
\hline 12 & $8 / 9 / 95$ & $33^{\circ} 10^{\prime} 11.22^{\prime \prime}$ & $81^{\circ} 37^{\prime} 58.47^{\prime \prime}$ & $17 \mathrm{ft} / \mathrm{M}$ & $1+/-1$ \\
\hline 12 & $8 / 9 / 95$ & $33^{\circ} 10^{\prime} 09.25^{\prime \prime}$ & $81^{\circ} 37^{\prime} 58.41^{\prime \prime}$ & $25 \mathrm{ft} / \mathrm{M}$ & $2+1-2$ \\
\hline 12 & $8 / 9 / 95$ & $33^{\circ} 10^{\prime} 06.43^{\prime \prime}$ & $81^{\circ} 37^{\prime} 56.42^{\prime \prime}$ & $48 \mathrm{ft} / \mathrm{M}$ & $1+/-2$ \\
\hline
\end{tabular}


Scoping Measurements of Radionuclides in L Lake with an Underwater HPGe Detector

\section{Appendix B. Data - Analysis of Sediments}

The sediment data analyzed in the ETS Underground Counting Facility is summarized below. The data are characterized according to their locations identified in Figure 7 . The table gives the following for each measurement:

- Sample identification

- Latitude and longitude

- Lake bottom depth

- ${ }^{60} \mathrm{Co}$ sample concentration (pCi/kg)

- ${ }^{137} \mathrm{Cs}$ sample concentration $(\mathrm{pCi} / \mathrm{kg})$

- ${ }^{60} \mathrm{Co} / 137 \mathrm{Cs}$ ratio (\%)

All entries are essentially self-explanatory; however, it should be pointed out that the concentrations are for the undried sediments. (The dried sediments would have somewhat greater concentrations). In the interest of providing timely results for the present scoping study, it was recognized that the data from the undried samples would be sufficient, as the prime interest was in examining the ${ }^{60} \mathrm{Co} /{ }^{137} \mathrm{Cs}$ ratio; however, even the absolute ${ }^{60} \mathrm{Co}$ and ${ }^{137} \mathrm{Cs}$ concentrations display the overall order-of-magnitude variations in the distribution, as the moisture content has a relatively minor effect on these trends.

An average of all the ${ }^{60} \mathrm{Co} /{ }^{137} \mathrm{Cs}$ ratios yields $1.79 \pm 0.24 \%$, where the error is the standard deviation of the mean. (The corresponding sample standard deviation is $1.08 \%$ ). Referring to Figure 3 , it is noted that two ratios are significantly larger at 3.27 and $5.98 \%$. Both values are in the vicinity of the $L$ Reactor discharge canal, where the earlier EG\&G overfight studies had indicated relatively greater amounts of ${ }^{60} \mathrm{Co}$. Excluding these two values, the ${ }^{60} \mathrm{Co} /{ }^{137} \mathrm{Cs}$ average is $1.47 \pm 0.08 \%$ (sample standard deviation of $0.32 \%$ ). This average value is considered more representative of the bulk of the lake, as the values making up this average span most locations of the lake and aiso cluster within a fairly narrower band about the average.

Table B. Data - Analyses of Sediment ${ }^{\mathrm{a}}$

\begin{tabular}{|c|c|c|c|c|c|c|}
\hline Sample ID & $\begin{array}{c}\text { Latitude } \\
\text { Deg 'Min'Sec" }\end{array}$ & $\begin{array}{c}\text { Longitude } \\
\text { Deg'Min'Sec" }\end{array}$ & Depth & $\begin{array}{l}\mathrm{Co}-60 \\
\mathrm{PC} / \mathrm{kg}\end{array}$ & $\begin{array}{l}\mathrm{Cs}-137 \\
\mathrm{pCi} / \mathrm{kg}\end{array}$ & $\begin{array}{c}\text { Co-60/Cs-137 } \\
\%\end{array}$ \\
\hline 72.2 & $33^{\circ} 10^{\prime} 08.65^{\prime \prime}$ & $81^{\circ} 38^{\prime} 03.25^{11}$ & 30 feet & $70.8+7-1.5$ & $823+1-8$ & $1.31+1-0.18$ \\
\hline $12-4$ & $33^{\circ} 10^{\prime} 11.22^{\prime \prime}$ & $81^{\circ} 37^{\prime} 58.47^{\prime \prime}$ & 17 feet & $3.0 \mathrm{MDA}$ & $242+/-4$ & $1.24 \mathrm{MDA}$ \\
\hline $12-6$ & $33^{\circ} 10^{\prime} 06.43^{\prime \prime}$ & $81^{\circ} 37^{\prime} 56.42^{\prime \prime}$ & 48 feet & $9.5+/-1.4$ & $593+/-6$ & $1.60+\delta-0.23$ \\
\hline $13-1$ & $33^{\circ} 10^{\prime} 01.99^{\prime \prime}$ & $81^{\circ} 37^{\prime} 55.55^{\prime \prime}$ & 28 feet & $3.3+/-0.8$ & $179+/-2$ & $1.84+/-0.43$ \\
\hline $13-2$ & $33^{\circ} 09^{\prime} 51.42^{\prime \prime}$ & $81^{\circ} 37^{\prime} 46.30^{\prime \prime}$ & 56 feet & $12.6+/-1.6$ & $836+/-10$ & $1.51+/-0.19$ \\
\hline $13-3$ & $33^{\circ} 09^{\prime} 55.60^{111}$ & $81^{\circ} 37^{\prime} 47.85^{\prime \prime}$ & 32 feet & $3.0 \mathrm{MDA}$ & $194+/-4$ & $1.55 \mathrm{MDA}$ \\
\hline 13.4 & $33^{\circ} 09^{\prime} 58.35^{\prime \prime}$ & $81^{\circ} 37^{\prime} 44.97^{\prime \prime}$ & 14 feet & $5.3+1-0.9$ & $338+/-5$ & $1.57+/-0.28$ \\
\hline $13-5$ & $33^{\circ} 09^{\prime} 55.32^{\prime \prime}$ & $81^{\circ} 38^{\prime} 14.39^{\prime \prime}$ & 14 feet & $2.9 \mathrm{MDA}$ & $268+1-2$ & $1.08 \mathrm{MDA}$ \\
\hline 14-1 & $33^{\circ} 12^{\prime} 22.46^{\prime \prime}$ & $81^{\circ} 36^{\prime} 42.97^{\prime \prime}$ & 10 feet & $91.7+/-2.5$ & $8190+/-20$ & $1.12+/-0.03$ \\
\hline $14-2$ & $33^{\circ} 12^{\prime} 19.17^{\prime \prime}$ & $81^{\circ} 36^{\prime} 57.09^{\prime \prime}$ & 16 feet & $330.7+1-3.7$ & $10700+/-200$ & $3.27+/-0.07$ \\
\hline $14-3$ & $33^{\circ} 11^{\prime} 58.65^{\prime \prime}$ & $81^{\circ} 37^{\prime} 15.45^{\prime \prime}$ & 22 feet & $152.0+/-2.7$ & $18100+/-100$ & $0.84+1-0.02$ \\
\hline$\overline{14-4}$ & $33^{\circ} 12^{\prime} 08.78^{11}$ & $81^{\circ} 37^{\prime} 27.46^{\prime \prime}$ & 12 feet & $71.8+/-2.2$ & $1200+/-10$ & $5.98+/ .0 .19$ \\
\hline $14-5^{b}$ & $33^{\circ} 11^{1} 46.09^{n}$ & $81^{\circ} 37^{\prime} 37.01^{\prime \prime}$ & 32 feet & $636.7+1-6.0$ & $34400+1-100$ & $1.85+1-0.02$ \\
\hline 14.6 & $33^{\circ} 111^{\prime} 33.00^{\prime \prime}$ & $81^{\circ} 37^{\prime} 56.99^{\prime \prime}$ & 40 feet & $284.8+1-4.6$ & $16200+1-200$ & $1.76+1-0.04$ \\
\hline 14.7 & $33^{\circ} 17^{\prime} 10.34^{\prime \prime}$ & $81^{\circ} 38^{\prime} 01.13^{\prime \prime}$ & 55 feet & $22.3+/-0.8$ & $1550+/-10$ & $1.44+1-0.05$ \\
\hline $14-8$ & $33^{\circ} 17^{\prime} 06.46^{\prime \prime}$ & $81^{\circ} 37^{\prime} 54.66^{\prime \prime}$ & 15 feet & $5.8+/-0.9$ & $292+/ .6$ & $1.99+/-0.32$ \\
\hline $14-9$ & $33^{\circ} 11^{\prime} 16.34^{\prime \prime}$ & $81^{\circ} 38^{\prime} 14.84^{\prime \prime}$ & 35 feet & $25.3+/-1.8$ & $1370+/-10$ & $1.85+/-0.13$ \\
\hline $14-10$ & $33^{\circ} 10^{\circ} 43.40^{\prime \prime}$ & $81^{\circ} 38^{\prime} 17.63^{\prime \prime}$ & 15 feet & $3.9+/-0.8$ & $250+/-4$ & $1.56+/-0.31$ \\
\hline $14-11$ & $33^{\circ} 10^{\prime} 33.69^{\prime \prime}$ & $81^{\circ} 38^{\prime} 06.01^{\prime \prime}$ & 54 feet & $23.2+/-1.6$ & $1700+/-10$ & $7.36+1-0.09$ \\
\hline 14-12 & $33^{\circ} 09^{1} 49.07^{\prime \prime}$ & $81^{\circ} 38^{\prime} 07.59^{\prime \prime}$ & 24 feet & $7.5+/-1.2$ & $742+/-7$ & $1.01+\delta-0.17$ \\
\hline
\end{tabular}

(a) Analysis decay-corrected to sample collection date of August 9, 1995

(b) Sample 14-5 indicated $28 \pm 5 \mathrm{pCi} / \mathrm{kg}$ for Eu-154 


\section{Appendix C. Dose Conversions}

\section{Dose Conversions for ${ }^{137} \mathrm{Cs}$}

For a gamma dose the roentgen $(\mathrm{R})$ and radiation-equivalent-man (rem) are identical numerically, since the quality factor (QF) is unity. The exposure $D(R / \mathrm{sec})$ for a flux of $\phi\left(\gamma / \mathrm{cm}^{2} / \mathrm{sec}\right)$ gammas with energy $E(\mathrm{MeV})$ is:

$$
\mathrm{D}(\mathrm{R} / \mathrm{sec})=1.82 \times 10^{-8} \phi\left(\gamma / \mathrm{cm}^{2} / \mathrm{sec}\right) \mathrm{E}(\mathrm{MeV}) \mu_{\mathrm{a}}\left(\mathrm{cm}^{2} / \mathrm{g}\right)
$$

where $\mu_{\mathrm{a}}\left(\mathrm{cm}^{2} / \mathrm{g}\right)$ is the mass attenuation coefficient for the gamma energy absorbed in the media. ${ }^{\mathrm{C} 1}$ Thus, for ${ }^{137} \mathrm{Cs}$ with $\mathrm{E}=0.662 \mathrm{MeV}$ and $\mu_{\mathrm{a}}=0.029 \mathrm{~cm}^{2} / \mathrm{g}$ for air $\mathrm{Cl}^{\mathrm{C}}$, the dose conversion in mrem/y becomes:

$$
\mathrm{D}(\mathrm{mrem} / \mathrm{y})=11.0 \phi\left(\gamma / \mathrm{cm}^{2} / \mathrm{sec}\right)\left[{ }^{137} \mathrm{Cs} \text { gammas }\right]
$$

To correlate the dose with the underwater HPGe detector ${ }^{137} \mathrm{Cs}$ count rate of its $0.662 \mathrm{MeV}$ gamma, information from the $\mathrm{Par}$ Pond study ${ }^{\mathrm{C3}}$ is used. Of particular importance is the point source detector calibration in air and its conversion to that for a planer slab source attenuated by water. For a point source centered below the detector just beneath its bottom screen (which defines the counting geometry on the lake bottom), the gamma flux $\phi$ and count rate $C$ are given as:

$$
\begin{aligned}
& \phi\left(\gamma / \mathrm{cm}^{2} / \mathrm{sec}\right)=\mathrm{G}(\gamma / \mathrm{sec}) / 4 \pi \mathrm{r}(\mathrm{cm})^{2} \\
& \mathrm{C}(\mathrm{cps})=\mathrm{G}(\gamma / \mathrm{sec}) \varepsilon_{\mathrm{p}}
\end{aligned}
$$

where $G(\gamma / \mathrm{sec})$ is the point source gamma emission rate, $r(\mathrm{~cm})$ is the source to detector distance, and $\varepsilon_{\mathrm{p}}$ is the point source efficiency for the gamma at this distance. From the earlier study ${ }^{C}$, the point source geometry in air for the $0.662 \mathrm{MeV}{ }^{137} \mathrm{Cs}$ gamma corresponded to $\mathrm{r}=5.0 \mathrm{in} .=12.7 \mathrm{~cm}$, and $\varepsilon_{\mathrm{p}}=0.002984$. Using these numerical values in the above equations, and then substituting the $\phi\left(\gamma / \mathrm{cm}^{2} / \mathrm{sec}\right)$ of Equation $\mathrm{C}-3$ into Equation $\mathrm{C}-2$ and dividing by Equation $\mathrm{C}-4$, the point source dose conversion is given by:

$$
\begin{gathered}
\mathrm{DC}_{\mathrm{p}}(\mathrm{mrem} / \mathrm{y} / \mathrm{cps})=\mathrm{D}(\mathrm{mrem} / \mathrm{y}) / \mathrm{C}(\mathrm{cps})=1.82 \mathrm{mrem} / \mathrm{y} / \mathrm{cps} \\
\text { or } \\
\mathrm{DC}_{\mathrm{p}}=0.0304 \mathrm{mrem} / \mathrm{y} / \mathrm{cpm}
\end{gathered}
$$

The general dose conversion for the detector placed on the lake bottom involves a correction factor of $\left\langle\mathrm{e}^{\mu \mathrm{r}}\right\rangle$ to address the water attenuation and extended slab source the detector sees, relative to the to point source dose conversion $\mathrm{DC}_{\mathrm{p}}$. Specifically, the desired dose conversion may be written:

$$
\left.\mathrm{DC}=\mathrm{DC}_{\mathrm{p}}<\mathrm{e}^{\mu \mathrm{r}}\right\rangle=0.0304\left\langle\mathrm{e}^{\mu \mathrm{r}}>\mathrm{rem} / \mathrm{y} / \mathrm{cpm}\right.
$$

The detector gamma flux $\phi\left(\gamma / \mathrm{cm}^{2} / \mathrm{sec}\right)$, efficiency, and count rate are all proportional, but it is necessary to calculate the gamma flux the detector would see in air - for count rate measured with the air replaced by water. The count rate in water would be lower by the ratio of the gamma fluxes in water and in air. For a uniform sediment slab source of thickness $s_{\mathrm{o}}$, a distance $h$ beneath the detector bottom screen, the flux ratio factor would be:

$$
\phi_{\mathrm{a}} / \phi_{\mathrm{w}}=\frac{\int_{0}^{\infty} \eta / 4 \pi \mathrm{r}^{2}\left(1-\mathrm{e}^{-\alpha \mathrm{s}}\right) / \alpha \mathrm{s} 2 \pi \mathrm{pdp} \mathrm{dz}}{\int_{0}^{\infty} \eta / 4 \pi \mathrm{r}^{2} \mathrm{e}^{-\mu \mathrm{t}}\left(1-\mathrm{e}^{-\beta \mathrm{s}}\right) / \beta \mathrm{s} 2 \pi \mathrm{pdpdz}}
$$


where $\eta$ is the uniform source density per unit volume, $p$ is the radial coordinate in the source plane, $z$ is the distance into the slab, $\mathrm{r}$ is the distance from a point $\mathrm{p}$ of the sediment surface to the detector, $s=s_{0} \tau / h$, and $\alpha, \beta$, and $\mu$ respectively are the attenuation coefficients for the dry sediment slab in air, the wet sediment slab in water, and the gamma path of length $t$ through the water. Because $r$ and $p$ are related by $r^{2}=p^{2}+h^{2}$, the differential expression $r d r=p d p$ is valid. In this work, $b$ $=5$ in $=12.7 \mathrm{~cm}$, a constant defined by the counting geometry. Using this substitution and cancelling constants, equation C- 6 becomes:

$$
\phi_{\mathrm{a}} / \phi_{\mathrm{w}}=\frac{\int_{\mathrm{h}}^{\infty} 1 / \mathrm{r}^{2}\left(1-\mathrm{e}^{-\alpha s}\right) / \alpha s \mathrm{rdr}}{\int_{\mathrm{h}}^{\infty} 1 / \mathrm{r}^{2} \mathrm{e}^{-\mu \mathrm{t}}\left(1-\mathrm{e}^{-\beta s}\right) / \beta s \mathrm{rdr}}
$$

Computer calculations for Equation C-7 were conducted for sediment thicknesses ranging $0-30 \mathrm{~cm}$, yielding $\phi_{2} / \phi_{\mathrm{w}}=\left\langle\mathrm{e}^{\mu \mathrm{r}}\right\rangle$ ranging 6.8-8.4, from which we choose a slightly conservative value of $\sim 10$. Per substitution into Equation $C-6$, this yields dose conversions $D C$ ranging $0.21-0.26 \mathrm{rem} / \mathrm{y} / \mathrm{cpm}$, from which a value of $-0.3 \mathrm{mrem} / \mathrm{y} / \mathrm{cpm}$ is selected for estimates in the present study. These calculations used: $t=r-r_{d}$, where $r_{d}=1.5$ in. $=3.81 \mathrm{~cm}$, the radius of the hemispherical can of the detector; $\alpha=0.5 \mu$ and $\beta=1.2 \mu$ based on the Par Pond study. ${ }^{\mathrm{C}}$

The preceding dose conversion for air was calculated for the detector distance above the surface, as opposed to the $1 \mathrm{~m}$ height referenced in the EG\&G overfight studies. However, little difference in dose is anticipated for the two heights, because although the $1 \mathrm{~m}$ height is further away from the surface, the self-attenuation of much of the sediment is reduced due to the better viewing angle. In other words, for the higher viewing position more source comes into view, such that the angle of the viewing cone remains about the same.

\section{Dose Conversions for ${ }^{60} \mathrm{Co}$}

The dose conversions for ${ }^{60} \mathrm{Co}$ are based on the ${ }^{60} \mathrm{Co} /{ }^{137} \mathrm{Cs}$ concentration ratios from the sediment samples to yield corresponding ${ }^{60} \mathrm{Co} /{ }^{137} \mathrm{Cs}$ dose ratios. From equation $\mathrm{C}-1$ we may express this dose ratio as

$$
\mathrm{DR}\left({ }^{60} \mathrm{Co} /{ }^{137} \mathrm{Cs}\right)=\frac{\mathrm{D}\left({ }^{60} \mathrm{Co}\right)}{\mathrm{D}\left({ }^{137} \mathrm{Cs}\right)}=\frac{\sum \phi\left(\mathrm{Co} \gamma^{\prime} \mathrm{s}\right) \mathrm{E}\left(\mathrm{Co} \gamma^{\prime} \mathrm{s}\right) \mu_{\mathrm{a}}\left(\mathrm{Co} \gamma^{\prime} \mathrm{s}\right)}{\Sigma \phi\left(\mathrm{Cs} \gamma^{\prime} \mathrm{s}\right) \mathrm{E}\left(\mathrm{Cs} \gamma^{\prime} \mathrm{s}\right) \mu_{\mathrm{a}}\left(\mathrm{Cs} \gamma^{\prime} \mathrm{s}\right)}
$$

The following are substituted in the above equation:

$$
\begin{array}{cccc} 
& \phi & \mathrm{k} \mathrm{C}\left({ }^{60} \mathrm{Co}\right) \times 1.00 & \mathrm{kC}\left({ }^{60} \mathrm{Co}\right) \times 1.00 \\
{ }^{60} \mathrm{Co} & \mathrm{E} & 1.173 \mathrm{MeV} & 1.332 \mathrm{MeV} \\
& \mu_{\mathrm{a}} & 0.027 \mathrm{~cm}^{2} / \mathrm{g} & 0.026 \mathrm{~cm}^{2} / \mathrm{g} \\
& & & \\
{ }^{137} \mathrm{Cs} & \phi & \mathrm{k} \mathrm{C}\left({ }^{137} \mathrm{Cs}\right) \times 0.85 & \\
& \mathrm{E} & 0.662 \mathrm{MeV} & \\
& \mu_{\mathrm{a}} & 0.029 \mathrm{~cm}^{2} / \mathrm{g} &
\end{array}
$$

where $k$ is a constant that converts radionuclide sediment concentrations $C\left({ }^{60} \mathrm{Co}\right)$ and $C\left({ }^{137} \mathrm{Cs}\right)$ to flux for a given geometry, and the respective multiplicitive factors $1.00,1.00$, and 0.85 are the gammas per decay. The resulting dose ratio is

$$
\mathrm{DR}\left({ }^{60} \mathrm{Co} /{ }^{137} \mathrm{Cs}\right)=4.06 \mathrm{C}\left({ }^{60} \mathrm{Co}\right) / \mathrm{C}\left({ }^{137} \mathrm{Cs}\right)=4.06 \mathrm{CR}\left({ }^{60} \mathrm{Co} /{ }^{137} \mathrm{Cs}\right)
$$

where $\mathrm{CR}\left({ }^{60} \mathrm{Co} /{ }^{137} \mathrm{Cs}\right)$ is the isotopic concentration ratio in the sediment. The above notations will be condensed to DR and $\mathrm{CR}$ for the remaining discussion. 
The text discusses consistency tests with this ratio that are detailed as follows. From Appendix B, a CR of $1.47 \pm 0.08 \%$ applied to the bulk of L Lake, and this yields a DR of $0.060 \pm 0.003$, which compares favorably a value of $0.053 \pm 0.006$ obtained from the EG\&G overflight contours. In another comparison, the maximum CR of $5.98 \pm 0.19 \%$ yielded a DR of $0.24 \pm 0.01$, which compares favorably with $0.27 \pm 0.10$ estimated from the EG\&G data. The basis for the estimates from the $E G \& G$ data are discussed below for each case above.

\section{Bulk DR of L Lake per EG\&G Data}

The major ${ }^{60} \mathrm{Co} 1985$ contours along the creek bed (between latitude lines $10.0 \mathrm{~min}$ and $12.1 \mathrm{~min}$ of Figure 8) are partitioned with $15 \% \mathrm{~B}$ contours (5-10 mrem) and $85 \% \mathrm{C}$ contours (10-20 mrem) for the 1985 values. The B contours are estimated to average about $8 \pm 1 \mathrm{mrem}$, since the creek bed does not pass the lower extremity of these contours. Similarly the C contours are estimated to average $13 \pm 1 \mathrm{mrem}$, as the stream bed does not pass through its upper contour. Thus, a weighted average of $0.15 \times 8+0.85 \times 13=12.25 \pm 0.86$ mrem results.

The ${ }^{137} \mathrm{Cs} 1985$ contours (Figure 6) along the same portion of creek bed as above include $\mathrm{E}$ (48-112 mrem) and F (112$240 \mathrm{mrem}$ ). The upper perimeter of the $E$ contour is very small; if it were zero, and the dose varied linearly between the contours, an average for $E$ would be estimated at $2 / 3 \times 48+1 / 3 \times 112=69 \mathrm{mrem}$; however, because, the upper contour is non-zero, a value of $75 \pm 5 \mathrm{mrem}$ is selected, being midway between the average of the contour limits of $80 \mathrm{mrem}$ and the above average. The F contours (112-240) make up about $5 \%$ along the creek bed, and their upper limit is not seen; an average of $140 \mathrm{mrem}$ is assumed. The weighted average of the $\mathrm{E}$ and $\mathrm{F}$ contours is $0.95 \times 75+0.05 \times 140=78 \pm 6$.

For the above data, the $1985 \mathrm{DR}$ for ${ }^{60} \mathrm{Co} /{ }^{137} \mathrm{Cs}$ is calculated as $(12.25 \pm 0.86) /(78 \pm 6)$, which when decayed to 1995 yields the value of $0.053 \pm 0.006$ mentioned earlier.

\section{Maximum DR of L Lake per EG\&G Data}

The maximum $D R$ are in the vicinity of the $L$ Reactor discharge canal. As a point for the calculation, we use the point in Figure 8 that is labeled by the " $\mathrm{C}$ " of the $\mathrm{C}$ contour nearest the discharge canal. This point, which is fairly close to the lower dose limit within its $1995{ }^{60} \mathrm{Co}$ contour $\mathrm{C}(2.7-5.4 \mathrm{mrem})$, is estimated to correspond to a dose of $3.0 \pm 0.3 \mathrm{mrem}$ for ${ }^{60} \mathrm{Co}$. The corresponding point for the ${ }^{137} \mathrm{Cs}$ plot of Figure 6 is within the $1995 \mathrm{~B}, \mathrm{C}$ contour (3-19 mrem). The point is estimated to have a dose of $11 \pm 4 \mathrm{mrem}$ for ${ }^{137} \mathrm{Cs}$, where the relatively large error is due to the unfortunately broad range of the contour. The resulting $1995 \mathrm{DR}$ for ${ }^{60} \mathrm{Co} /{ }^{137} \mathrm{Cs}$ is calculated to be $(3.0 \pm 0.3) /(11 \pm 4)=0.27 \pm 0.10$ as noted earlier.

\section{Appendix C References}

C1. H. Cember, Introduction to Health Physics, Pergamon Press, New York (1969).

C2. R. D. Evans, The Atomic Nucleus, McGraw-Hill, New York (1955).

C3. Reference 4 of main text (see page 10). 


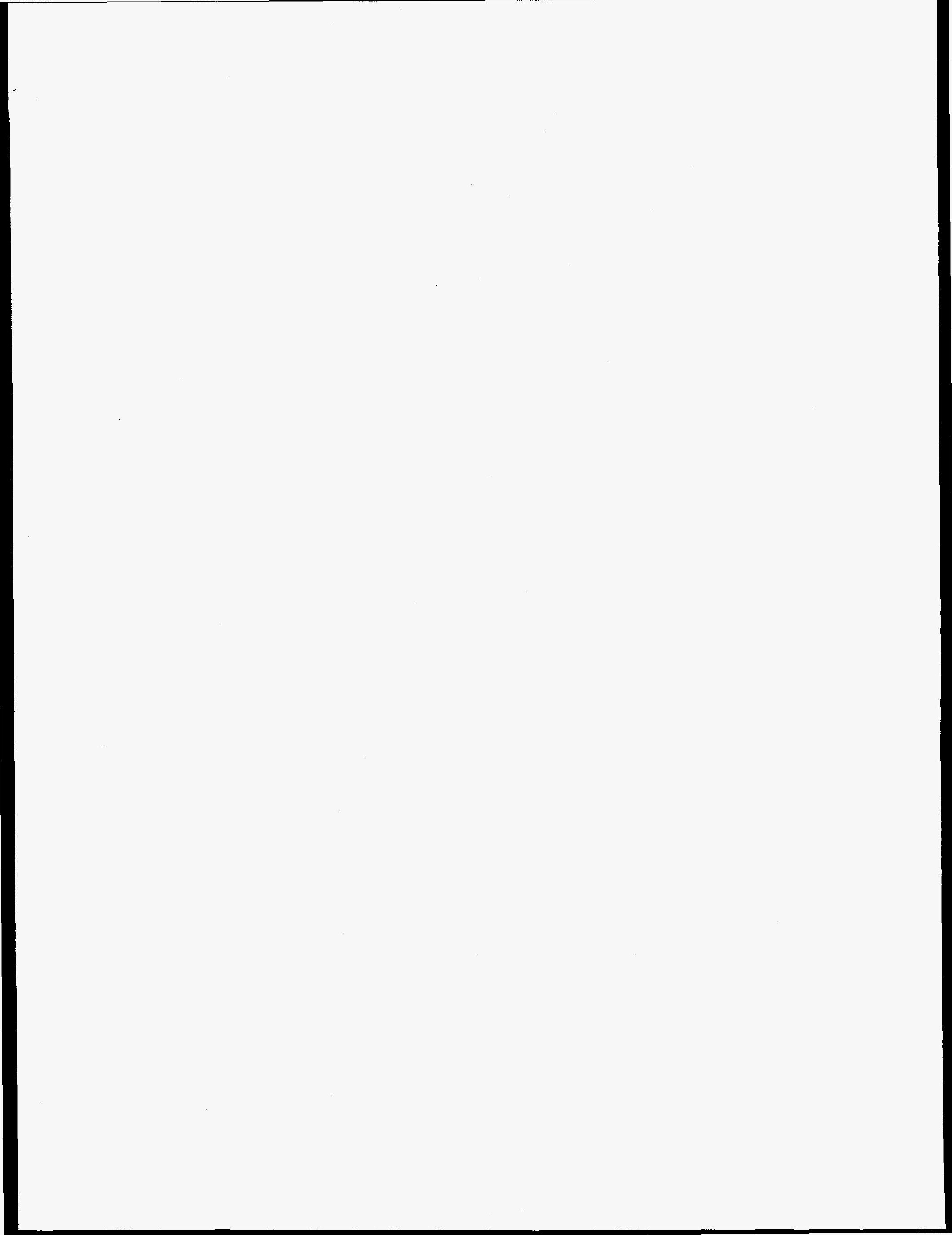

